\title{
Highly Active and Durable Co-Doped Pt/CCC Cathode Catalyst for Polymer Electrolyte Membrane Fuel Cells
}

\author{
Wonsuk Jung, Tianyuan Xie, Taekeun Kim, Prabhu Ganesan, Branko N. Popov* \\ Center for Electrochemical Engineering, Department of Chemical Engineering, University of \\ South Carolina, Columbia, SC 29208 \\ Technical Paper Submitted to Electrochimica Acta \\ Prof. A. Robert Hilman \\ Dept. of Chemistry, University of Leicester, \\ University Road, Leicester, LE1 7RH, UK \\ arh7@le.ac.uk
}

December 2014

* Corresponding author

Branko N. Popov

Tel: 0018037777314

Fax: 0018037778265

Email: popov@cec.sc.edu 


\begin{abstract}
Cathode catalyst based on Co-doped Pt deposited on carbon composite catalyst (CCC) support with high measured activity and stability under potential cycling conditions for polymer electrolyte membrane (PEM) fuel cells was developed in this study. The catalyst was synthesized through platinum deposition on Co-doped CCC support containing pyridinic-nitrogen active sites followed by controlled heat-treatment. High resolution transmission electron microscopy (HRTEM) and X-ray diffraction (XRD) studies confirmed uniform Pt deposition (Pt/CCC catalyst, $\left.\mathrm{d}_{\mathrm{Pt}}=2 \mathrm{~nm}\right)$ and formation of Co-doped Pt/CCC catalyst $\left(\mathrm{d}_{\mathrm{Pt}}=5.4 \mathrm{~nm}\right)$ respectively. $\mathrm{X}$ ray energy dispersive spectrometry (XEDS) line-scan studies showed the formation of Co-core Pt-shell type catalyst with a Pt-shell thickness of $\sim 0.75 \mathrm{~nm}$. At $0.9 \mathrm{~V}_{\mathrm{iR} \text {-free, }}$ the Co-doped Pt/CCC catalyst showed initial mass activity of $0.44 \mathrm{~A} \mathrm{mg}_{\mathrm{Pt}}{ }^{-1}$ and $0.25 \mathrm{~A} \mathrm{mg}_{\mathrm{Pt}}{ }^{-1}$ after 30,000 potential cycles between 0.6 and $1.0 \mathrm{~V}$ corresponding to an overall measured activity loss of $42.8 \%$. The commercial Pt-Co/C showed initial mass activity of $0.38 \mathrm{~A} \mathrm{mg}_{\mathrm{Pt}}{ }^{-1}$ and $\sim 70 \%$ loss of activity after 30,000 cycles. The enhanced catalytic activity at high potentials and stability of mass activity for the Co-doped Pt/CCC catalyst are attributed to the formation of compressive Pt lattice catalyst due to Co doping. The Co-doped Pt/CCC showed stable open circuit potential close to $1.0 \mathrm{~V}$ under $\mathrm{H}_{2}$-air with an initial power density of $857 \mathrm{~mW} \mathrm{~cm}^{-2}$ and only $16 \%$ loss after 30,000 cycles. Catalyst durability studies performed between 0.6 and $1.0 \mathrm{~V}$ indicated that Co doping increased the onset potential for $\mathrm{PtO}_{2}$ formation close to $1.0 \mathrm{~V}$ vs. reversible hydrogen electrode (RHE). The enhanced catalytic activity and stability of Co-doped Pt/CCC catalyst are attributed to (i) higher onset potential for $\mathrm{PtO}_{2}$ formation resulting in less $\mathrm{PtO}_{2}$ formation during potential cycling which alleviates Pt dissolution in the reverse scan (ii) higher stability of CCC used as a support compared with commercially used supports, and (iii) optimized electrochemical
\end{abstract}


properties of the catalyst and the support which results in the synergistic effect between pyridinic nitrogen catalytic sites from the Co-doped CCC support and compressive Pt-lattice catalyst.

Key words: Polymer electrolyte membrane fuel cells, Carbon composite catalyst support, Cobalt doping, Core-shell catalyst, Mass activity, potential cycling. 


\section{Introduction}

Polymer electrolyte membrane fuel cells (PEMFCs) are attractive power sources of the future for variety of applications including portable electronics, stationary power, and electric vehicles. However, sluggish cathode kinetics, high Pt cost, and durability issues inhibit the use of PEMFCs for automobile applications $[1,2]$. A number of factors contribute to the performance degradation of PEMFCs including catalyst dissolution [3-8], catalyst sintering [7, 9], membrane degradation [10-12], and carbon support corrosion [13-17].

One of the efforts in achieving increased catalytic activity is by alloying $\mathrm{Pt}$ with $3 \mathrm{~d}$ transition metals to obtain high mass activity at $0.9 \mathrm{~V}_{\mathrm{iR} \text {-free }}$ for oxygen reduction reaction (ORR) [18-23]. In PEMFCs, Pt-alloys with various transition metals such as $\mathrm{Cr}, \mathrm{Co}, \mathrm{Ni}$, etc. have been extensively studied and shown superior electrocatalytic activity for the ORR when compared to pure Pt [21-25]. The enhancement in measured activity over Pt by alloying Pt with transition metals is due to various factors including lowering of the Pt oxidation state [26], suppression of Pt oxide formation [26, 27], formation of a new electronic structure with higher Pt $5 \mathrm{~d}$ orbital vacancies [19], decrease in the Pt-Pt interatomic distance and therefore a more favorable $\mathrm{O}_{2}$ adsorption [19], formation of a thin Pt skin on the surface of the alloy core [28-30], and the altered electronic structures of the topmost Pt atoms [21, 22, 31].

Amongst the Pt-alloy catalysts, the PtCo catalyst has attracted much attention due to its high activity and stability in acidic environment [25, 32]. Paulus et al. studied the bulk compositions of 50 and 75 at.\% $\mathrm{Pt}$ with $\mathrm{Ni}$ and $\mathrm{Co}$ as alloying elements $[20,33]$. In comparison to pure $\mathrm{Pt}$, the results revealed a small activity enhancement of ca. 1.5 times for the 25 at. $\% \mathrm{Ni}$ and Co catalysts, and a more significant enhancement by a factor of $2-3$ for the 50 at.\% Co. Huang et al. showed that PtCo alloy nanoparticles exhibit measured activity and specific activity 
enhancements by a factor of $\sim 1.3-3.2$ and $\sim 1.2-2.2$, respectively for the ORR when compared to pure Pt [34]. Antolini et al. reviewed the catalyst activity and stability, and concluded that $\mathrm{PtCr}$ and $\mathrm{PtCo}$ are more stable than $\mathrm{PtV}, \mathrm{PtNi}$, and $\mathrm{PtFe}$ due to their high degree of alloying and particle size [25]. Jayasayee et al. studied the activity and durability of PtCo, PtNi, and PtCu in PEMFC cathodes as a function of alloying elements in a systematic manner [23]. They showed that the performance of PtCo and PtCu catalysts was found to be most attractive when compared to PtNi and Pt catalysts. Mani et al. investigated the activity of dealloyed $\mathrm{PtCu}, \mathrm{PtCo}$, and $\mathrm{PtNi}$ in PEMFCs [24]. They found that Pt-alloy with $\mathrm{Co}$ and $\mathrm{Cu}$ are more active than PtNi. Mass and specific activities of PtCo and $\mathrm{PtCu}$ were enhanced by a factor of 3-4 times, compared to the commercial Pt/C catalyst.

The durability of carbon-supported PtCo catalysts is the core advantage as cathode catalysts in PEMFCs. Yu et al. studied the durability of $\mathrm{Pt} / \mathrm{C}$ and $\mathrm{PtCo} / \mathrm{C}$ cathode catalysts with continuous water fluxing on the cathode under a potential cycling test between 0.87 and $1.2 \mathrm{~V}$ vs. RHE [35]. The authors found that cobalt dissolution neither detrimentally reduced the cell voltage nor dramatically affected the membrane conductance. Cell performance enhancement by $\mathrm{PtCo} / \mathrm{C}$ over Pt/C catalyst was sustained over 2400 cycles and the overall performance loss of the $\mathrm{PtCo} / \mathrm{C}$ membrane electrode assemblies (MEAs) was less than that of the Pt/C MEA. Arico et al. reported the performance and durability of carbon-supported PtCo under high temperature (110$130{ }^{\circ} \mathrm{C}$ ) operation in PEMFCs [36]. A potential cycling test at $130{ }^{\circ} \mathrm{C}$ in a pressurized PEMFC showed a better stability for the PtCo alloy than pure Pt/C. Furthermore, better performance was obtained at high temperatures for the pre-leached $\mathrm{PtCo} / \mathrm{C}$ than the $\mathrm{Pt} / \mathrm{C}$ catalyst. They observed that the amount of Pt oxides on the outermost atomic layers was much smaller in PtCo than in $\mathrm{Pt}$ catalyst. These characteristics appeared to influence catalysts' performance and durability. Stassi 
et al. investigated the effect of thermal treatment on the structure and surface composition of PtCo catalysts during accelerated stress test (AST) [37]. They reported that different thermal treatments caused significant structural and morphological modifications in the PtCo catalysts. Yu et al. studied the cycling stability of dealloyed $\mathrm{PtCo}_{3}$ and $\mathrm{PtCu}_{3}$ catalysts between 0.6 and 1.0 V (vs. RHE) for up to 30,000 cycles [38]. In situ X-ray absorption spectroscopy (XAS) analysis showed stronger bulk Pt-Pt compressive strains and higher bulk d-band vacancies for the dealloyed $\mathrm{PtCu}_{3}$ than the dealloyed $\mathrm{PtCo}_{3}$ which was correlated to the higher initial activity of dealloyed $\mathrm{PtCu}_{3}$. MEA tests showed poor durability towards voltage cycling for the dealloyed $\mathrm{PtCu}_{3}$ catalyst when compared to dealloyed $\mathrm{PtCo}_{3}$ catalyst due to $\mathrm{Cu}$ plating on the anode.

In general, $\mathrm{PtM}_{3}(\mathrm{M}=\mathrm{Cu}, \mathrm{Co}, \mathrm{Ni}, \mathrm{Fe}, \mathrm{Cr})$ catalysts are prepared by impregnating excess amount of transition metal salts into Pt/C catalyst followed by a heat-treatment under a reducing atmosphere and acid leaching procedures $[24,38,39]$. Since excess transition metal salts are used for the catalyst synthesis, the leaching is carried out in strong acids for prolonged time which may be detrimental to the support stability when the cathode experiences high potentials during startup/shutdown cycles. In our previous studies, we reported a novel method of preparing Co-doped Pt catalysts supported on carbon composite catalyst (CCC) supports $[3,40,41]$. In the present study, Co was initially doped into the carbon black at high temperature using metalcatalyzed pyrolysis which was used as a transition metal source for the formation of Co-doped Pt. The Co-doped carbon prepared in this manner was used as a support to deposit Pt nanoparticles (Pt/CCC catalyst synthesis). The Pt supported on Co-doped carbon was heat-treated under reducing atmosphere to obtain Co-doped Pt catalyst with controlled particles size. During heattreatment, Co, which is doped within the carbon, diffuses to the surface and forms Co-doped Pt catalyst with a core-shell structure. The activity and durability of activity of Co-doped Pt 
prepared by the novel approach were examined and compared with those of commercial $\mathrm{Pt}-\mathrm{Co} / \mathrm{C}$ as well as state-of-the-art Pt/C catalyst [42, 43].

\section{Experimental}

\subsection{Preparation of support and catalyst}

The CCC support was prepared using the procedure developed at University of South Carolina [40, 41, 44-48]. In brief, as-received carbon (Ketjen Black EC-300J) was oxidized with $9.8 \mathrm{M} \mathrm{HNO}_{3}$ solution at $85{ }^{\circ} \mathrm{C}$ for $9 \mathrm{~h}$ under refluxing conditions. After filtering, the oxidized carbon black was washed with DI water several times and dried under vacuum at $80{ }^{\circ} \mathrm{C}$ for $12 \mathrm{~h}$. A desired amount of $\mathrm{Co}\left(\mathrm{NO}_{3}\right)_{2}$ and ethylene diamine, used as Co and $\mathrm{N}$ precursors, respectively, were mixed with the oxidized carbon black in $200 \mathrm{ml}$ isopropyl alcohol. The mol ratio of Co and $\mathrm{N}$ precursors was maintained at 1:9. The mixture was reflexed for $3 \mathrm{~h}$ at $85{ }^{\circ} \mathrm{C}$ under vigorous stirring, followed by drying under vacuum at $80{ }^{\circ} \mathrm{C}$. The resultant powder was subjected to heattreatment under inert atmosphere at $800{ }^{\circ} \mathrm{C}$ for $1 \mathrm{~h}$ followed by leaching in $0.5 \mathrm{M} \mathrm{H}_{2} \mathrm{SO}_{4}$ at $80{ }^{\circ} \mathrm{C}$ for $3 \mathrm{~h}$ to remove excess $\mathrm{Co}$. The final product is denoted as CCC.

Pt deposition was accomplished by a polyol reduction method for the preparation of $30 \%$ $\mathrm{Pt} / \mathrm{CCC}$ catalyst. First, the CCC support was dispersed in $25 \mathrm{ml}$ of ethyleneglycol in a sonication bath (Branson ultrasonic cleaner). A desired amount of $\mathrm{PtCl}_{4}$ was added and the $\mathrm{pH}$ was adjusted to 11 by the addition of $0.1 \mathrm{M} \mathrm{NaOH}$ solution. The resulting solution was refluxed at $160{ }^{\circ} \mathrm{C}$ for $3 \mathrm{~h}$ and allowed to cool to room temperature. Then, the solution was filtered, washed with DI water, and dried at $160{ }^{\circ} \mathrm{C}$ for $1 \mathrm{~h}$. Prior to heat-treatment, the Pt/CCC was subjected to a protective coating procedure using polyaniline. Oxidative polymerization of aniline sulfate was carried out at room temperature using ammonium peroxysulfate as the oxidizing agent [46-48]. The polyaniline-coated Pt/CCC was placed in an alumina crucible and heat-treated at $800{ }^{\circ} \mathrm{C}$ for 
$2 \mathrm{~h}$ in a tubular furnace under $5 \% \mathrm{H}_{2}$ (balance $\mathrm{N}_{2}$ ) atmosphere. The catalyst thus prepared is denoted as Co-doped Pt/CCC.

\subsection{Physical characterization}

The nitrogen adsorption/desorption isotherms were obtained at $-196{ }^{\circ} \mathrm{C}$ using a Quantachrome NOVA 2000 BET analyzer. Specific surface area was determined by a multipoint Brunauer-Emmett-Teller (BET) analysis. Pore size distribution (PSD) curves were calculated by the Barrett-Joyner-Halenda (BJH) method using the adsorption/desorption branch. X-ray diffraction (XRD) analysis was performed using a Rigaku D/Max 2500 V/ PC with a $\mathrm{Cu} \mathrm{K} \alpha$ radiation. A tube voltage of $30 \mathrm{kV}$ and a current of $15 \mathrm{~mA}$ were used during the scanning. To estimate the particle size of samples, we employed the following Scherrer equation [40, 41]:

$$
D=\frac{k \lambda}{10 B \cos \theta}
$$

where $\mathrm{D}$ is the crystallite size in $\mathrm{nm}, \mathrm{k}$ is a coefficient $(0.9), \lambda$ is the wavelength of $\mathrm{X}$-ray (1.5404 $\AA$ ), $\mathrm{B}$ is the line broadening at half the maximum intensity in radians, and $\theta$ is the angle at the position of the maximum peak known as Bragg angle. Raman spectroscopy was used to evaluate the degree of graphitization of the carbon supports using HORIBA "LABRAM 1B" (He-Ne 20mW laser, wave length $632.817 \mathrm{~nm}$ ). Inductively coupled plasma atomic emission spectroscopy (ICP, Perkin Elmer) analysis was used to determine the composition of the catalysts. High resolution transmission electron microscope (HRTEM) was used to study the morphology and particles size distribution of the catalysts using Hitachi 9500 HRTEM operated at $300 \mathrm{kV}$ accelerating voltage. X-ray fluorescence (XRF, Fischer XDAL) was used to determine PtCo composition in the catalyst and Pt loading in the catalyst coated membrane. 


\subsection{MEA fabrication and electrochemical measurement}

The in-house synthesized Co-doped Pt/CCC catalyst was employed as the cathode catalyst while commercial $46 \% \mathrm{Pt} / \mathrm{C}$ was used as a catalyst for the anode. Catalyst inks were prepared by ultrasonically mixing the respective catalysts $(32 \mathrm{mg}$ ), isopropyl alcohol (IPA, 1.8 $\mathrm{ml})$, Nafion ${ }^{\circledR}$ ionomer (5\% solution, Alfa Aesar), and DI water $(0.2 \mathrm{ml})$. The ionomer content was $30 \%$ and $20 \%$ in the anode and cathode inks, respectively. The catalyst inks were sprayed directly on the Nafion ${ }^{\circledR} 212$ membrane covering an active area of $25 \mathrm{~cm}^{2}$. The Pt loading on the anode and cathode electrodes is kept at $0.1 \mathrm{mg} \mathrm{cm}^{-2}$. The catalyst coated membrane was then hot pressed at $140{ }^{\circ} \mathrm{C}$ using a pressure of $20 \mathrm{~kg} \mathrm{~cm}^{-2}$ for $6 \mathrm{~min}$. in between the gas diffusion layers (Sigracet GDL 10BC, SGL) and Teflon gaskets to prepare the membrane electrode assembly (MEA) for the performance evaluation studies in fuel cell.

Initially, the MEA was activated under a supply of $\mathrm{H}_{2}$ and $\mathrm{O}_{2}$ at $80{ }^{\circ} \mathrm{C}$ to the anode and cathode compartments, respectively with a flow rate of $750 \mathrm{ml} \mathrm{min}^{-1}$ and $100 \%$ relative humidity (RH). After MEA activation, the initial mass activity at $0.9 \mathrm{~V}_{\mathrm{iR} \text {-free }}$ was evaluated under $\mathrm{H}_{2} / \mathrm{O}_{2}$ (2/9.5 stoic.) at $80{ }^{\circ} \mathrm{C}, 100 \% \mathrm{RH}$, and $150 \mathrm{kPa}_{\text {abs. }}$ back pressure. The electrochemical surface area (ECSA) was estimated using cyclic voltammetry experiments carried out between 0.05 and $0.6 \mathrm{~V}$ (vs. RHE) at $80{ }^{\circ} \mathrm{C}$ under fully humidified $\mathrm{H}_{2}$ and $\mathrm{N}_{2}$ supply to the anode and the cathode, respectively. In accelerated stressed test (AST), $200 \mathrm{sccm} \mathrm{H}_{2}$ and $75 \mathrm{sccm} \mathrm{N} \mathrm{N}_{2}$ were supplied to the anode and cathode, respectively and the potential was swept between 0.6 and $1.0 \mathrm{~V}$ (vs. RHE) at $50 \mathrm{mV} \mathrm{s}^{-1}$ in a triangle profile for up to 30,000 cycles [52] since it has been estimated that the cathode catalysts undergo 30,000 potential cycles under automotive operating conditions [53]. The fuel cell polarization was conducted using a fully automated fuel cell test station (Scribner Associates Inc., model 850e) at $80{ }^{\circ} \mathrm{C}$. The mass activity and ECSA measurements 
were performed after $0,1000,5000,10,000,20,000$, and 30,000 cycles. For comparison purposes, MEAs with commercial Pt-Co/C (TEC36EA52, 46.8\% Pt and 6.7\% Co, Tanaka Kikinzoku Kogyo K.K, Japan) and 46\% Pt/C (TEC10E50E, Tanaka Kikinzoku Kogyo K.K, Japan) as cathode catalysts were also prepared and evaluated under the same experimental conditions.

\section{Results and discussion}

\subsection{CCC support synthesis}

Figure 1 illustrates the schematic diagram of the approach used to synthesize CCC and metal-doped Pt/CCC. Surface modification on the carbon support introduces oxygen and nitrogen groups on the surface [40]. The metal-catalyzed pyrolysis increases the carbon graphitization degree in the presence of cobalt at high temperatures $\left(800 \sim 900{ }^{\circ} \mathrm{C}\right)$, introduces 7 $15 \%$ Co in the carbon matrix, and incorporates nonmetallic (nitrogen-containing) active sites on the carbon surface. Next, the chemical leaching removes excess Co used to dope the support. Modified polyol process was used for uniform platinum deposition [40, 41]. In the next step, the Co doped in the CCC diffuses to the surface to form Co-doped Pt catalysts during heat-treatment in the presence of polyaniline protective coating [40]. The heat-treatment process was optimized to control the particle size between 3-5 nm, resulting in compressive Pt-lattice catalyst having Ptshell/doped metal core structure.

Figure 2 (a) and (b) show the nitrogen adsorption-desorption isotherms and BJH PSD curves of CCC and Ketjen black (KB). The specific surface area of CCC and KB are 398, and $826.4 \mathrm{~m}^{2} \mathrm{~g}^{-1}$, respectively. The CCC exhibits characteristic Type IV adsorption/desorption isotherm behavior according to IUPAC classification indicating its mesoporous nature [54]. The isotherms show hysteresis loop with sharp adsorption and desorption branches over a relative 
pressure range of 0.4-0.8. The nitrogen uptake is observed when $\left(\mathrm{P} / \mathrm{P}_{0}\right)$ ratio is $0.94-1.0$, which indicates the presence of mesopores [54]. The total pore volume was reduced from 0.846 to $0.688 \mathrm{ml} \mathrm{g}^{-1}$. As shown in Figure 2(b) inset, after the metal-catalyzed pyrolysis the peak pore diameter is ca. $4 \mathrm{~nm}$.

Figure 3 (a) presents XRD patterns of the $\mathrm{CCC}$ and $\mathrm{KB}$. Generally the characteristic diffraction peaks of (002) and (101) planes for carbon are found at ca. 26 and $43^{\circ}$. The diffraction peaks of CCC are sharper with increased intensity and shift to more positive angles. Consequently, the interlayer spacing of CCC based on (002) plane decreases to $0.3456 \mathrm{~nm}$, while that of $\mathrm{KB}$ is $0.3615 \mathrm{~nm}$. The results indicated that the carbon surface of CCC has been partially graphitized during metal-catalyzed pyrolysis. Furthermore, the CCC shows characteristic diffraction peaks at $44.2,51.5$, and $75.8^{\circ}$ which correspond to the (111), (200), and (220) planes of face centered cubic (fcc) structure of Co metal particle (PDF\#97-007-6632), respectively. The XRD results confirm the presence of Co metal after acid-leaching at $80{ }^{\circ} \mathrm{C}$. Additionally, Figure 3 (b) reveals the Raman spectra for $\mathrm{CCC}$ and $\mathrm{KB}$. Both $\mathrm{CCC}$ and $\mathrm{KB}$ show the D band and $\mathrm{G}$ band at approximately 1350 and $1580 \mathrm{~cm}^{-1}$, respectively. The D band originates from structural defects and disorder-induced features on carbon, while the $\mathrm{G}$ band corresponds to the stretching vibration mode of graphite crystals $[55,56]$. Relative ratio of $D$ band to the $G$ band $\left(\mathrm{I}_{\mathrm{D}} / \mathrm{I}_{\mathrm{G}}\right)$ for $\mathrm{CCC}$ and $\mathrm{KB}$ is estimated to be 2.42 and 2.60 , respectively, indicating that $\mathrm{CCC}$ is more graphitized than KB.

The HRTEM images of CCC (after acid leaching) and KB are shown in Figure 4 (a) and (b), respectively. The apparent difference between them is the presence of Co particles encapsulated by carbon shells in the CCC support since the Co particles present on the surface are removed during acid leaching. Nanostructured fibers or tubes of graphitic carbon are also 
formed as a result of pyrolysis in the presence of Co metal $[57,58]$ while KB showed amorphous morphology as shown in Figure 4(b). ICP-AES analysis of CCC indicated a cobalt content of $\sim 13 \mathrm{wt} . \%$ in the CCC synthesized at $800{ }^{\circ} \mathrm{C}$.

The results of XPS analysis performed on CCC and KB supports are presented in Figure 5(a) and (b), respectively. Figure 5 (a) shows the survey scans for CCC and KB. Only XPS spectrum of CCC, as shown in Figure 5(b), exhibits a broad peak around $398.9 \mathrm{eV}$ which corresponds to the nitrogen atom. The nitrogen peak shown in Figure 5 (b) for CCC can be deconvoluted into four major peaks corresponding to pyridinic, pyrrolic and/or pyridone, quaternary, and pyridinic- $\mathrm{N}^{+}-\mathrm{O}^{-}$(oxidized nitrogen). The peak at $398.4 \mathrm{eV}$ accounts for the presence of pyridinic- $\mathrm{N}$ whereas the peak at $400.3 \mathrm{eV}$ corresponds to the pyrrolic- $\mathrm{N}$ and/or pyridine- $\mathrm{N}$. The peaks at 401.1 and $403.4 \mathrm{eV}$ are ascribed to the presence of quaternary- $\mathrm{N}$ and pyridinic- $\mathrm{N}^{+}-\mathrm{O}^{-}$, respectively. Relative percentages of pyridinic- $\mathrm{N}$ and pyrrolic- $\mathrm{N}$ and/or pyridine- $\mathrm{N}$ are 41 and $38.5 \%$ of total nitrogen, respectively. Quaternary-N accounts for $6.6 \%$ while pyridinic- $\mathrm{N}^{+}-\mathrm{O}^{-}$occupies $13.9 \%$. It is well-known that pyridinic- $\mathrm{N}$ situated on the edge of the graphite planes promotes ORR by donating one p-electron to the aromatic $\pi$ system [58-60]. Moreover, previous studies report that the quaternary- $\mathrm{N}$ plays a role as stable ORR active sites $[48,56-58]$.

\subsection{Co-doped Pt/CCC catalyst synthesis}

The elemental compositions in the bulk of Pt/CCC and Co-doped Pt/CCC catalysts were determined using ICP-AES and XRF. Initially, the metal-catalyzed pyrolysis resulted in $\sim 13 \mathrm{wt} . \%$ Co within the partially graphitized CCC support synthesized at $800{ }^{\circ} \mathrm{C}$. As described earlier, the novelty of the process is to use the Co particles embedded in the CCC support for the formation of Co-doped Pt catalyst when subjected to heat-treatment at $800{ }^{\circ} \mathrm{C}$ for $2 \mathrm{~h}$ under $5 \% \mathrm{H}_{2}$. ICP- 
AES and XRF analyses indicated initial Pt:Co atomic ratios of 1:1 and 1.1:1, respectively for Pt/CCC and Co-doped Pt/CCC catalysts.

To confirm Co doping into Pt, XRD patterns of fresh Pt/CCC and Co-doped Pt/CCC (2 h heat-treated) are shown in Figure 6. The characteristic diffraction peaks of fresh Pt/CCC at 39.8, 46.25, 67.7, and $81.25^{\circ}$ correspond to the (111), (200), (220) and (311) planes of pure Pt, respectively, while those at $44.2,51.5$, and $75.8^{\circ}$ are ascribed to (111), (200), and (220) planes of pure Co, respectively (Figure 6 inset). Both the catalysts exhibit the characteristics of the Pt with fcc structure. In Figure 6 inset, the characteristic peaks of pure Co are observed in Pt/CCC, since the CCC contains Co encapsulated within the CCC support. As the heating progresses, the peaks of Co and Pt are shifted to lower and higher angles, respectively and Co doping into the Pt lattice is observed as indicated by the shift in $\operatorname{Pt}(111)$ peak to higher angles. Our earlier study showed that, when the Co-doped Pt/CCC is heat-treated for more than $2 \mathrm{~h}$, the diffraction peaks of Codoped Pt (111) is fixed at $41.35^{\circ}$ [40]. The lattice parameter of Co-doped Pt/CCC (3.7786 $\AA$ ) is smaller than that of the Pt/CCC (3.9195 $\AA$ ) due to the strain caused by the Co doping into the Pt host lattice. This result indicates that the Co particles embedded within the CCC support diffused to the surface during heat-treatment and formed Co-doped Pt catalyst particles.

The HRTEM images of Pt/CCC, Co-doped Pt/CCC, commercial Pt-Co/C, and commercial Pt/C are shown in Figure 7 (a), (b), (c), and (d), respectively. The average particle sizes and the particle size distribution were measured using an average of 100 nanoparticles. The Pt nanoparticles are deposited with uniform size and distribution on the CCC support. The mean particle size is approximately 2.5, 5.4, 6, and $2.4 \mathrm{~nm}$ for the Pt/CCC, Co-doped Pt/CCC, commercial $\mathrm{Pt}-\mathrm{Co} / \mathrm{C}$, and commercial $\mathrm{Pt} / \mathrm{C}$, respectively. For the $\mathrm{Pt} / \mathrm{CCC}$ catalyst, $\mathrm{Pt}$ nanoparticles uniformly deposit on the support and 2-3 nm-sized particles are dominant. Most of 
the particles in Co-doped Pt/CCC catalyst are in the range of 4-7 nm while a few large particles are shown due to the high temperature treatment, but well-distributed on the support. However, the commercial Pt-Co/C showed majority of the particles in the range 5-6 nm with considerable number of particles that are above $10 \mathrm{~nm}$ and as high as $20 \mathrm{~nm}$.

\subsection{Evaluation of initial mass activity and durability of mass activity at $0.9 V_{i R \text {-free }}$}

The initial mass activities and stability of mass activities of Co-doped Pt/CCC, commercial $\mathrm{Pt}-\mathrm{Co} / \mathrm{C}$, and commercial $\mathrm{Pt} / \mathrm{C}$ catalysts at $0.9 \mathrm{~V}_{\mathrm{iR} \text {-free }}$ are shown in Figure $8(\mathrm{a})$, Figure 8(b), and Figure 8(c), respectively. The mass activity is defined as the ORR rate per gram of Pt measured at $0.9 \mathrm{~V}_{\mathrm{iR} \text {-free }}$ [52]. The activity measurements were performed using the AST protocol suggested by U.S DRIVE Fuel Cell Tech Team. The Co-doped Pt/CCC shows much higher mass activity $\left(0.44 \mathrm{~A} \mathrm{mg}_{\mathrm{P}_{\mathrm{t}}}{ }^{-1}\right)$ at $0.9 \mathrm{~V}_{\mathrm{iR} \text {-free }}$ than the commercial Pt-Co/C $\left(0.38 \mathrm{~A} \mathrm{mg}_{\mathrm{Pt}^{-1}}\right)$ and commercial Pt/C (0.18 $\left.\mathrm{A} \mathrm{mg}_{\mathrm{Pt}}{ }^{-1}\right)$ catalysts due to the formation of Co-doped Pt core and Ptrich shell type catalyst particles with compressive Pt lattice during annealing [22, 64-66]. When transition metals such as Co are used to modify Pt, two major electronic effects namely, strain effect and ligand effect, are induced within the Pt host lattice [67-70]. The strain effect leads to a decrease in the Pt-Pt interatomic distance when compared to pure Pt while the ligand effect results in the modification of the surface electronic structure due to hetero-metallic bonding interactions [68].

The line-scan of XEDS results for Co-doped Pt/CCC (fresh) is shown in Figure 9. The fresh Co-doped Pt/CCC shows an initial Pt-rich layer thickness of $\sim 0.75 \mathrm{~nm}$. From density functional theory simulations, it has been postulated that the optimized Pt skin thickness is 2 to 3 monolayers which is equal to $0.50-0.75 \mathrm{~nm}[71,72]$. It has also been reported that the ligand effects are only effective up to 1-3 atomic layers [69] and the geometric effects can modify the 
Pt-Pt interatomic distances up to 7 atomic layers [73]. Since the Pt-shell thickness in Co-doped $\mathrm{Pt} / \mathrm{CCC}$ is $\sim 3$ atomic layers, the increased ORR activity can be attributed to the combination of ligand and geometric effects resulted from Co doping in the Pt lattice.

The mass activity degradation tendencies of Co-doped Pt/CCC, commercial Pt-Co, and Pt/C catalysts are summarized in Figure 10. The figure shows a linear decrease until 20,000 cycles and stabilized after 20,000 cycles for all the three catalysts. The initial and after 30,000 cycles measured activities of Co-doped Pt/CCC, commercial Pt-Co/C, and Pt/C catalysts are summarized in Table 2. After 30,000 cycles, the overall mass activity losses are ca. 43\%, 69\%, and $64 \%$ for $\mathrm{Co}-$ doped $\mathrm{Pt} / \mathrm{CCC}$, commercial $\mathrm{Pt}-\mathrm{Co} / \mathrm{C}$, and commercial $\mathrm{Pt} / \mathrm{C}$, respectively. Furthermore, the Co-doped Pt/CCC still retained a significant amount of mass activity (0.24 A $\mathrm{mg}_{\mathrm{P}_{\mathrm{t}}}{ }^{-1}$ ) after 30,000 cycles which is much higher than that of initial mass activity of $\mathrm{Pt} / \mathrm{C}$ catalysts reported in literature $[39,74]$. This may be due to the fact that the Co dissolution rate in Co-doped $\mathrm{Pt} / \mathrm{CCC}$ is much smaller than that in commercial $\mathrm{Pt}-\mathrm{Co} / \mathrm{C}$ and $\mathrm{Co}$ doping has increased the durability of Co-doped Pt/CCC catalyst under potential cycling conditions. After potential cycling between 0.6 and $1.0 \mathrm{~V}$, thick Pt skin $(\sim 1.8 \mathrm{~nm})$ is formed on the catalyst due to $\mathrm{Pt}$ dissolution/re-deposition (Figure 11), which is still active for the ORR as indicated by the high mass activity even after 30,000 cycles. The thick Pt skin reduces the electronic effect in Codoped Pt [71] which may be one of the reasons for the mass activity loss besides the wellexplained Pt particle agglomeration effect [75]. On the other hand, Co from commercial Pt-Co/C catalyst is rapidly dissolved after 10,000 cycles and the mass activity reached a value which is close to that of initial value for the Pt/C catalyst. Thus, after 10,000 cycles, the commercial Pt$\mathrm{Co} / \mathrm{C}$ catalyst performs like a pure $\mathrm{Pt} / \mathrm{C}$ catalyst and further performance degradation is caused 
by the Pt dissolution and redeposition mechanism which occurs at higher rate than the one observed for Co-doped Pt/CCC.

To further understand the loss in measured activity, the normalized ECSAs calculated for Co-doped $\mathrm{Pt} / \mathrm{CCC}$, commercial $\mathrm{Pt}-\mathrm{Co} / \mathrm{C}$, and $\mathrm{Pt} / \mathrm{C}$ catalysts as a function of cycle number are shown in Figure 12. Initial ECSA values of 75, 68, and $75 \mathrm{~m}^{2} \mathrm{~g}_{\mathrm{Pt}}{ }^{-1}$ were obtained for Co-doped $\mathrm{Pt} / \mathrm{CCC}$, commercial Pt-Co/C, and commercial Pt/C catalysts, respectively. Lower degradation rate for Co-doped Pt/CCC is observed in Figure 12 after 10,000 cycles when compared to commercial Pt-Co/C and Pt/C catalysts. After 30,000 cycles, $64 \%, 21 \%$, and $18 \%$ of initial ECSA are retained for Co-doped Pt/CCC, commercial Pt-Co/C, and commercial Pt/C catalysts, respectively, which indicate that the Co-doped $\mathrm{Pt} / \mathrm{CCC}$ is remarkably stable when compared to commercial $\mathrm{Pt}-\mathrm{Co} / \mathrm{C}$ and $\mathrm{Pt} / \mathrm{C}$ catalysts. The HRTEM images of Co-doped Pt/CCC and commercial Pt/C after AST are shown in Figure 13 (a) and (b), respectively. After AST, the mean particle size of Co-doped Pt/CCC and Pt/C increased to $6.2 \mathrm{~nm} 7.3 \mathrm{~nm}$, respectively and the particle size distribution based on the histograms represents that the particle size of Co-doped $\mathrm{Pt} / \mathrm{CCC}$ still exhibits good catalyst dispersion and no extensive agglomeration is observed. On the other hand, the $\mathrm{Pt} / \mathrm{C}$ shows large particles $(>10 \mathrm{~nm}$ ) and significant catalyst agglomeration indicating poor particle distribution. Since the ECSA and particle agglomeration are related to the catalyst activity, the measured activity of Co-doped Pt/CCC is more stable than that of commercial Pt-Co and Pt/C catalysts.

XRD studies were performed to investigate the structural changes in Co-doped Pt/CCC catalyst before and after AST as shown in Figure 14. After the AST, the Co-doped Pt/CCC shows obvious Bragg angle shift to lower angles. The lattice parameter for the Co-doped Pt/CCC catalyst increased from 3.8006 to $3.9082 \AA$. The increased lattice parameter after AST is similar 
to that of pure Pt which indicates that the catalyst surface is modified with thick Pt-rich layer during potential cycling experiment. The Co on the catalyst surface is removed electrochemically during potential cycling between 0.6 and $1.0 \mathrm{~V}$, and the dissolution/redeposition of Pt occurs on the catalyst particles. As a result, thick Pt-enriched layer is formed on the catalyst particles. Recent reports attributed the structural and compositional changes to the degradation of Pt-Co catalyst stability [76]. Furthermore, the peak shift of Pt-Co catalyst toward lower angle was ascribed to the formation of Pt-rich shell due to Co dissolution [77]. Hidai et al., using Co 2p soft X-ray photoemission spectroscopy (SXPES) spectra of the cycle-tested Pt-Co catalyst, showed absence of cobalt on the surface of catalyst particles and the presence of thick Pt skin layer $(>1.4$ $\mathrm{nm})$ on the catalyst surface [78].

The composition of Co-doped Pt/CCC catalyst before and after AST was examined using XRF (Table 1). The results indicated that the initial Pt:Co atomic ratio (1.1:1) for the fresh Co-doped Pt/CCC increased to 2.3:1 after 30,000 cycles due to the dissolution of Co from the catalyst during potential cycling. Previous studies have also showed Pt-Co catalyst degradation under fuel cell operating conditions due to rapid leaching of Co and formation of a "Pt skeleton" structure at the topmost surface layer within the first few hours of operation $[79,80]$. Further degradation makes a Pt-enriched shell/Pt-Co core structure due to Co surface segregation/leaching and Ostwald ripening of $\mathrm{Pt}[79,80]$. It has been found that the Co content in the bulk Pt-Co decreased and Co concentration of near-surface Pt-Co was lower than the bulk concentration after degradation $[78,79]$.

Table 2 compares measured activities in $\mathrm{H}_{2}-\mathrm{O}_{2}$ at $0.9 \mathrm{~V}_{\mathrm{iR} \text {-free, }}$ open circuit potentials (OCP) in $\mathrm{H}_{2}$-air, and maximum power density in $\mathrm{H}_{2}$-air fuel cell for Co-doped $\mathrm{Pt} / \mathrm{CCC}$, commercial Pt$\mathrm{Co} / \mathrm{C}$, and commercial Pt/C catalysts. The OCP measurements indicated stable and very high 
values for the Co-doped Pt/CCC during the entire potential cycling period. Specifically, the OCP after 10,000 cycles is close to $1.0 \mathrm{~V}$ which may be attributed to the Co dissolution and formation of Pt-rich surface layer during potential cycling. The Co-doped Pt/CCC showed initial power density of $857 \mathrm{~mW} \mathrm{~cm}^{-2}$ with a loss of only $16 \%$ after 30,000 cycles under $\mathrm{H}_{2}$-air fuel cell operating conditions. On the other hand, the commercial $\mathrm{Pt}-\mathrm{Co} / \mathrm{C}$ and $\mathrm{Pt} / \mathrm{C}$ catalysts showed initial power densities of 482 and $746 \mathrm{~mW} \mathrm{~cm}^{-2}$, respectively and very high power density losses of 48 and $63 \%$, respectively after 30,000 cycles. The drastic performance degradation for the commercial $\mathrm{Pt}-\mathrm{Co} / \mathrm{C}$ and $\mathrm{Pt} / \mathrm{C}$ catalysts can be attributed to Ostwald ripening, $\mathrm{Pt}$ dissolution and redeposition $[3-9,40,70]$. Furthermore, the $\mathrm{H}_{2}-\mathrm{O}_{2}$ fuel cell polarization under constant flow of 750/750 sccm shown in Figure 15 indicates no performance degradation when the cathode reactant is sufficiently supplied for ORR at $100 \% \mathrm{RH}$ since the Co-doped $\mathrm{Pt} / \mathrm{CCC}$ catalyst maintains the catalytic activity before and after 30,000 cycles. However, our previous study indicated a significant performance loss for the commercial Pt/C catalyst under the same operating conditions [40]. It has been reported that water activation and Pt-OH formation on PtCo catalyst surface is shifted to higher potentials when compared to pure Pt $[20,81,82]$. The cyclic voltammograms recorded in rotating ring disk electrode (RRDE) for Co-doped Pt/CCC and Pt/CCC catalysts shown in Figure 16 indicate a shift in Pt-OH formation by $\sim 40 \mathrm{mV}$ for the Co-doped Pt/CCC when compared to Pt/CCC. Figure 16 also shows two regions namely, $\mathrm{H}$ adsorption/desorption below $0.4 \mathrm{~V}$ and oxygen-related reactions (Pt oxidation/reduction) between 0.6 and 1.0 V. During potential cycling from 0.6 to $1.0 \mathrm{~V}$, Pt oxides are formed according to the following reactions [83]:

$$
\begin{aligned}
& \mathrm{Pt}+\mathrm{H}_{2} \mathrm{O} \rightarrow \mathrm{PtO}+2 \mathrm{H}^{+}+2 e^{-} \\
& \mathrm{Pt}+2 \mathrm{H}_{2} \mathrm{O} \rightarrow \mathrm{PtO}_{2}+4 \mathrm{H}^{+}+4 e^{-}
\end{aligned}
$$


At high potentials, adsorbed oxygen $\left(\mathrm{Pt}-\mathrm{O}_{\mathrm{ad}}\right)$ is formed due to water oxidation:

$$
\mathrm{Pt}+\mathrm{H}_{2} \mathrm{O} \rightarrow \mathrm{Pt}-\mathrm{O}_{a d}+2 \mathrm{H}^{+}+2 e^{-}
$$

In the reverse scan from 1.0 to $0.6 \mathrm{~V}$, platinum oxides are reduced to $\mathrm{Pt}$ according to the following reactions:

$$
\begin{gathered}
\mathrm{PtO}+2 \mathrm{H}^{+}+2 e^{-} \rightarrow \mathrm{Pt}+\mathrm{H}_{2} \mathrm{O} \\
\mathrm{PtO}_{2}+4 \mathrm{H}^{+}+4 e^{-} \rightarrow \mathrm{Pt}+2 \mathrm{H}_{2} \mathrm{O} \\
\mathrm{Pt}-\mathrm{O}_{\mathrm{ad}}+2 \mathrm{H}^{+}+2 e^{-} \rightarrow \mathrm{Pt}+\mathrm{H}_{2} \mathrm{O}
\end{gathered}
$$

The potential shift for Pt oxidation to higher values, as indicated by the higher OCP observed in $\mathrm{H}_{2}$-air polarization curve, increases the mass activity (from 0.15 to $>0.4 \mathrm{~A} \mathrm{mg}_{\mathrm{Pt}}{ }^{-1}$ ) due to the suppression of Pt oxide formation which has much lower exchange current density for ORR $\left(\mathrm{i}^{\mathrm{O}}\right.$ $\left.=1.7 \times 10^{-10} \mathrm{~A} \mathrm{~cm}^{-2}\right)$ when compared to pure $\mathrm{Pt}\left(\mathrm{i}^{\mathrm{O}}=2.8 \times 10^{-7} \mathrm{~A} \mathrm{~cm}^{-2}\right)$ [84]. Besides the effect of higher mass activity, Co-doped Pt catalyst also illustrates improved stability when compared to pure Pt catalyst. Since Pt oxide dissolves during potential cycling conditions according to Eq. (8), less $\mathrm{PtO}_{2}$ formation in the forward scan due to higher Pt oxidation potential in the case of Codoped Pt/CCC catalyst alleviates Pt dissolution in the reverse scan and enhances the catalyst stability.

$$
\mathrm{PtO}_{2}+4 \mathrm{H}^{+}+2 e^{-} \rightarrow \mathrm{Pt}^{2+}+2 \mathrm{H}_{2} \mathrm{O}
$$

However, in automotive applications at applied potentials of $\sim 0.6-0.7 \mathrm{~V}$, only pure Pt catalytic sites will be present on the catalyst surface for ORR at high current regions due to electrochemical reduction of Pt oxides formed when the cathode catalyst is subjected to high potentials during startup/shutdown cycles and/or fuel starvation. Thus, the $\mathrm{H}_{2} /$ air performance at low potentials will not be greatly affected as much as in the case of mass activity which is measured at $0.9 \mathrm{~V}_{\mathrm{iR}-\text { free }}$ 


\section{Conclusion}

A novel procedure was developed for the synthesis of Co-doped Pt on carbon composite catalyst (CCC) using Co-doped CCC as a support, which contains pyridinic-nitrogen active sites, through platinum deposition and heat-treatment procedures. High resolution transmission electron microscopy indicated uniform $\mathrm{Pt}$ deposition for the $\mathrm{Pt} / \mathrm{CCC}$ and Co-doped $\mathrm{Pt} / \mathrm{CCC}$ catalysts with average particle sizes of 2 and $5.4 \mathrm{~nm}$, respectively. X-ray energy dispersive spectrometry line-scan studies showed Co-core Pt-shell type catalyst formation with a Pt-shell thickness of $\sim 0.75 \mathrm{~nm}$. The Co-doped Pt/CCC catalyst showed initial mass activity of $0.44 \mathrm{~A}$ $\mathrm{mg}_{\mathrm{Pt}}{ }^{-1}$ and $0.25 \mathrm{~A} \mathrm{mg}_{\mathrm{Pt}}{ }^{-1}$ at $0.9 \mathrm{~V}_{\mathrm{iR}-\text { free }}$ after 30,000 potential cycles between 0.6 and $1.0 \mathrm{~V}$ while the commercial Pt-Co/C showed initial mass activity of $0.38 \mathrm{~A} \mathrm{mg}_{\mathrm{Pt}}^{-1}$ and $\sim 70 \%$ loss of activity after 30,000 cycles. The Co-doped Pt/CCC showed stable open circuit potential close to $1.0 \mathrm{~V}$ under $\mathrm{H}_{2}$-air with an initial power density of $857 \mathrm{~mW} \mathrm{~cm}^{-2}$ and only $16 \%$ loss after 30,000 cycles. The enhanced catalytic activity and stability of Co-doped Pt/CCC catalyst are attributed to: (i) higher onset potential for $\mathrm{PtO}_{2}$ formation which results in less $\mathrm{PtO}_{2}$ formation during potential cycling and alleviates Pt dissolution in the reverse scan, thus enhancing the catalyst stability, (ii) enhanced stability of CCC used as a support, and (iii) optimized electrochemical properties of the catalyst and the support resulting in the synergistic effect between pyridinic nitrogen catalytic sites from the Co-doped CCC support and compressive Pt-lattice catalyst.

\section{Acknowledgement}

The financial support of U.S. Department of Energy (contract no. DE-EE0000460) is gratefully acknowledged. 


\section{References}

[1] H.A. Gasteiger, S.S. Kocha, B. Sompalli, F.T. Wagner, Activity benchmarks and requirements for Pt, Pt-alloy, and non-Pt oxygen reduction catalysts for PEMFCs, Appl. Catal. B: Environ. 56 (2005) 9-35.

[2] R. Makharia, S.S. Kocha, P.T. Yu, M.A. Sweikart, W. Gu, F.T. Wagner, H.A. Gasteiger, Durable PEM fuel cell electrode materials: Requirements and benchmarking methodologies, ECS Trans., 1 (2006) 3-18.

[3] X. Li, H.R. Colón-Mercado, G. Wu, J.-W. Lee, B.N. Popov, Development of method for synthesis of Pt-Co cathode catalysts for PEM fuel cells, Electrochemical and Solid-State Lett., 10 (2007) B201-B205.

[4] J. Wu, X.Z. Yuan, J.J. Martin, H. Wang, J. Zhang, J. Shen, S. Wu, W. Merida, A review of PEM fuel cell durability: Degradation mechanisms and mitigation strategies, J. Power Sources, 184 (2008) 104-119.

[5] Y. Sugawara, A.P. Yadav, A. Nishikata, T. Tsuru, EQCM Study on anodic dissolution of platinum in acid solutions, Electrochemistry, 75 (2007) 359-365.

[6] P.J. Ferreira, G.J. la O’, Y. Shao-Horn, D. Morgan, R. Makharia, S. Kocha, H.A. Gasteiger, Instability of $\mathrm{Pt} / \mathrm{C}$ electrocatalysts in proton exchange membrane fuel cells: A mechanistic investigation, J. Electrochem. Soc., 152 (2005) A2256-A2271.

[7] S. Mitsushima, S. Kawahara, K.-i. Ota, N. Kamiya, Consumption rate of Pt under potential cycling, J. Electrochem. Soc., 154 (2007) B153-B158.

[8] F. Kodera, Y. Kuwahara, A. Nakazawa, M. Umeda, Electrochemical corrosion of platinum electrode in concentrated sulfuric acid, J. Power Sources, 172 (2007) 698-703. 
[9] R. Borup, J. Davey, F. Garzon, D. Wood, P. Welch, K. More, PEM fuel cell durability with transportation transient operation, ECS Trans., 3 (2006) 879-886.

[10] V.A. Sethuraman, J.W. Weidner, A.T. Haug, L.V. Protsailo, Durability of perfluorosulfonic acid and hydrocarbon membranes: Effect of humidity and temperature, J. Electrochem. Soc., 155 (2008) B119-B124.

[11] M. Crum, W. Liu, Effective testing matrix for studying membrane durability in PEM fuel cells: Part 2. Mechanical durability and combined mechanical and chemical durability, ECS Trans., 3 (2006) 541-550.

[12] A. Laconti, H. Liu, C. Mittelsteadt, R. McDonald, Polymer electrolyte membrane degradation mechanisms in fuel cells - Findings over the past 30 years and comparison with electrolyzers, ECS Trans., 1 (2006) 199-219.

[13] S.-Y. Huang, P. Ganesan, S. Park, B.N. Popov, Development of a titanium dioxide-supported platinum catalyst with ultrahigh stability for polymer electrolyte membrane fuel cell applications, J. Am. Chem. Soc., 131 (2009) 13898-13899.

[14] S.D. Knights, K.M. Colbow, J. St-Pierre, D.P. Wilkinson, Aging mechanisms and lifetime of PEFC and DMFC, J. Power Sources, 127 (2004) 127-134.

[15] L.M. Roen, C.H. Paik, T.D. Jarvi, Electrocatalytic corrosion of carbon support in PEMFC cathodes, Electrochem. Solid-State Lett., 7 (2004) A19-A22.

[16] Y. Shao, G. Yin, J. Zhang, Y. Gao, Comparative investigation of the resistance to electrochemical oxidation of carbon black and carbon nanotubes in aqueous sulfuric acid solution, Electrochim. Acta, 51 (2006) 5853-5857.

[17] B. Avasarala, R. Moore, P. Haldar, Surface oxidation of carbon supports due to potential cycling under PEM fuel cell conditions, Electrochim. Acta, 55 (2010) 4765-4771. 
[18] C.J. Tseng, S.T. Lo, S.C. Lo, P.P. Chu, Characterization of Pt-Cu binary catalysts for oxygen reduction for fuel cell applications, Mater. Chem. Phys., 100 (2006) 385-390.

[19] M.-k. Min, J. Cho, K. Cho, H. Kim, Particle size and alloying effects of Pt-based alloy catalysts for fuel cell applications, Electrochim. Acta, 45 (2000) 4211-4217.

[20] U.A. Paulus, A. Wokaun, G.G. Scherer, T.J. Schmidt, V. Stamenkovic, V. Radmilovic, N.M. Markovic, P.N. Ross, Oxygen reduction on carbon-supported Pt-Ni and Pt-Co alloy catalysts, J. Phys. Chem. B, 106 (2002) 4181-4191.

[21] V.R. Stamenkovic, B.S. Mun, M. Arenz, K.J.J. Mayrhofer, C.A. Lucas, G. Wang, P.N. Ross, N.M. Markovic, Trends in electrocatalysis on extended and nanoscale Pt-bimetallic alloy surfaces, Nat. Mater., 6 (2007) 241-247.

[22] V. Stamenkovic, B.S. Mun, K.J.J. Mayrhofer, P.N. Ross, N.M. Markovic, J. Rossmeisl, J. Greeley, J.K. Nørskov, Changing the activity of electrocatalysts for oxygen reduction by tuning the surface electronic structure, Angew. Chem. Int. Ed., 45 (2006) 2897-2901.

[23] K. Jayasayee, J.A.R.V. Veen, T.G. Manivasagam, S. Celebi, E.J.M. Hensen, F.A. de Bruijn, Oxygen reduction reaction (ORR) activity and durability of carbon supported PtM $(\mathrm{Co}, \mathrm{Ni}, \mathrm{Cu})$ alloys: Influence of particle size and non-noble metals, Appl. Catal. B-Environ., 111-112 (2012) $515-526$.

[24] P. Mani, R. Srivastava, P. Strasser, Dealloyed binary $\mathrm{PtM}_{3}(\mathrm{M}=\mathrm{Cu}, \mathrm{Co}, \mathrm{Ni})$ and ternary $\mathrm{PtNi}_{3} \mathrm{M}(\mathrm{M}=\mathrm{Cu}, \mathrm{Co}, \mathrm{Fe}, \mathrm{Cr})$ electrocatalysts for the oxygen reduction reaction: Performance in polymer electrolyte membrane fuel cells, J. Power Sources, 196 (2011) 666-673.

[25] E. Antolini, J.R.C. Salgado, E.R. Gonzalez, The stability of Pt-M ( $M$ = first row transition metal) alloy catalysts and its effect on the activity in low temperature fuel cells: A literature review and tests on a Pt-Co catalyst, J. Power Sources, 160 (2006) 957-968. 
[26] A.S. Aricò, A.K. Shukla, H. Kim, S. Park, M. Min, V. Antonucci, An XPS study on oxidation states of $\mathrm{Pt}$ and its alloys with $\mathrm{Co}$ and $\mathrm{Cr}$ and its relevance to electroreduction of oxygen, Appl. Surf. Sci., 172 (2001) 33-40.

[27] A.K. Shukla, M. Neergat, P. Bera, V. Jayaram, M.S. Hegde, An XPS study on binary and ternary alloys of transition metals with platinized carbon and its bearing upon oxygen electroreduction in direct methanol fuel cells, J. Electroanal. Chem., 504 (2001) 111-119.

[28] T. Toda, H. Igarashi, H. Uchida, M. Watanabe, Enhancement of the electroreduction of oxygen on Pt alloys with Fe, Ni, and Co, J. Electrochem. Soc., 146 (1999) 3750-3756.

[29] T. Toda, H. Igarashi, M. Watanabe, Role of electronic property of Pt and Pt alloys on electrocatalytic reduction of oxygen, J. Electrochem. Soc., 145 (1998) 4185-4188.

[30] V. Stamenković, T.J. Schmidt, P.N. Ross, N.M. Marković, Surface composition effects in electrocatalysis: Kinetics of oxygen reduction on well-defined $\mathrm{Pt}_{3} \mathrm{Ni}$ and $\mathrm{Pt}_{3} \mathrm{Co}$ alloy surfaces, $\mathrm{J}$. Phys. Chem. B, 106 (2002) 11970-11979.

[31] V.R. Stamenkovic, B. Fowler, B.S. Mun, G. Wang, P.N. Ross, C.A. Lucas, N.M. Marković, Improved oxygen reduction activity on $\mathrm{Pt}_{3} \mathrm{Ni}(111)$ via increased surface site availability, Science, 315 (2007) 493-497.

[32] Y. Hoshi, T. Yoshida, A. Nishikata, T. Tsuru, Dissolution of Pt-M (M: Cu, Co, Ni, Fe) binary alloys in sulfuric acid solution, Electrochim. Acta, 56 (2011) 5302-5309.

[33] U.A. Paulus, A. Wokaun, G.G. Scherer, T.J. Schmidt, V. Stamenkovic, N.M. Markovic, P.N. Ross, Oxygen reduction on high surface area Pt-based alloy catalysts in comparison to well defined smooth bulk alloy electrodes, Electrochim. Acta, 47 (2002) 3787-3798.

[34] Q. Huang, H. Yang, Y. Tang, T. Lu, D.L. Akins, Carbon-supported Pt-Co alloy nanoparticles for oxygen reduction reaction, Electrochem. Commun., 8 (2006) 1220-1224. 
[35] P. Yu, M. Pemberton, P. Plasse, PtCo/C cathode catalyst for improved durability in PEMFCs, J. Power Sources, 144 (2005) 11-20.

[36] A. Salvatore Aricò, A. Stassi, I. Gatto, G. Monforte, E. Passalacqua, V. Antonucci, Surface properties of Pt and PtCo electrocatalysts and their influence on the performance and degradation of high-temperature polymer electrolyte fuel cells, J. Phys. Chem. C, 114 (2010) 15823-15836.

[37] A. Stassi, I. Gatto, G. Monforte, V. Baglio, E. Passalacqua, V. Antonucci, A.S. Aricò, The effect of thermal treatment on structure and surface composition of PtCo electro-catalysts for application in PEMFCs operating under automotive conditions, J. Power Sources, 208 (2012) 3545.

[38] Z. Yu, J. Zhang, Z. Liu, J.M. Ziegelbauer, H. Xin, I. Dutta, D.A. Muller, F.T. Wagner, Comparison between dealloyed $\mathrm{PtCo}_{3}$ and $\mathrm{PtCu}_{3}$ cathode catalysts for proton exchange membrane fuel cells, J. Phys. Chem. C, 116 (2012) 19877-19885.

[39] B. Han, C.E. Carlton, A. Kongkanand, R.S. Kukreja, B.R. Theobald, L. Gan, R. O’Malley, P. Strasser, F.T. Wagner, Y. Shao-Horn, Record activity and stability of dealloyed bimetallic catalysts for proton exchange membrane fuel cells, Energ. Environ. Sci., DOI: $10.1039 / C 4 E E 02144 D$.

[40] T. Xie, W.S. Jung, T. Kim, P. Ganesan, B.N. Popov, Development of highly active and durable hybrid cathode catalysts for polymer electrolyte membrane fuel cells, J. Electrochem. Soc., 161 (2014) F1489-F1501.

[41] T. Kim, T. Xie, W.S. Jung, F. Gadala-Maria, P. Ganesan, B.N. Popov, Development of catalytically active and highly stable catalyst supports for polymer electrolyte membrane fuel cells, J. Power Sources, 273 (2015) 761-774. 
[42] B. Arumugam, B.A. Kakade, T. Tamaki, M. Arao, H. Imai, T. Yamaguchi, Enhanced activity and durability for the electroreduction of oxygen at a chemically ordered intermetallic PtFeCo catalyst, RSC Adv., 4 (2014) 27510-27517.

[43] S. Du, Y. Lu, S.K. Malladi, Q. Xu, R. Steinberger-Wilckens, A simple approach for PtNiMWCNT hybrid nanostructures as high performance electrocatalysts for the oxygen reduction reaction, J. Mater. Chem. A, 2 (2014) 692-698.

[44] N.P. Subramanian, S.P. Kumaraguru, H. Colon-Mercado, H. Kim, B.N. Popov, T. Black, D.A. Chen, Studies on Co-based catalysts supported on modified carbon substrates for PEMFC cathodes, J. Power Sources, 157 (2006) 56-63.

[45] V. Nallathambi, J.-W. Lee, S.P. Kumaraguru, G. Wu, B.N. Popov, Development of high performance carbon composite catalyst for oxygen reduction reaction in PEM Proton Exchange Membrane fuel cells, J. Power Sources, 183 (2008) 34-42.

[46] N.P. Subramanian, X. Li, V. Nallathambi, S.P. Kumaraguru, H. Colon-Mercado, G. Wu, J.W. Lee, B.N. Popov, Nitrogen-modified carbon-based catalysts for oxygen reduction reaction in polymer electrolyte membrane fuel cells, J. Power Sources, 188 (2009) 38-44.

[47] X. Li, G. Liu, B.N. Popov, Activity and stability of non-precious metal catalysts for oxygen reduction in acid and alkaline electrolytes, J. Power Sources, 195 (2010) 6373-6378.

[48] G. Liu, X. Li, P. Ganesan, B.N. Popov, Studies of oxygen reduction reaction active sites and stability of nitrogen-modified carbon composite catalysts for PEM fuel cells, Electrochim. Acta, 55 (2010) 2853-2858.

[49] J. Stejskal, R.G. Gilbert, Polyaniline. Preparation of a conducting polymer, Pure and Appl. Chem., 74 (2002) 857-867. 
[50] S. Ghatak, G. Chakraborty, A.K. Meikap, T. Woods, R. Babu, W.J. Blau, Synthesis and characterization of polyaniline/carbon nanotube composites, J. Appl. Polym. Sci., 119 (2011) 1016-1025.

[51] Q.-F. Lü, Z.-W. He, J.-Y. Zhang, Q. Lin, Fabrication of nitrogen-containing hollow carbon nanospheres by pyrolysis of self-assembled poly(aniline-co-pyrrole), J. Anal. Appl. Pyrol., 93 (2012) 147-152.

[52] U.S. DRIVE Fuel Cell Technical Team “Cell Component Accelerated Stress Test and Polarization Curve Protocols for PEM Fuel Cells," (January 14 2014) http://www.uscar.org/guest/teams/17/Fuel-Cell-Tech-Team.

[53] F.T. Wagner, H.A. Gasteiger, R. Makharia, K.C. Neyerlin, E.L. Thompson, S.G. Yan, Catalyst development needs and pathways for automotive PEM fuel cells, ECS Transactions, 3 (2006) 19-29.

[54] K.S.W. Sing, D.H. Everett, R.A.W. Haul, L. Moscou, R.A. Pierotti, J. Rouquerol, T. Siemieniewska, Reporting physisorption data for gas/solid systems with special reference to the determination of surface area and porosity (recommendations 1984), Pure and Appl. Chem., 57 (1985) 603-619.

[55] C. Kim, S.-H. Park, J.-I. Cho, D.-Y. Lee, T.-J. Park, W.-J. Lee, K.-S. Yang, Raman spectroscopic evaluation of polyacrylonitrile-based carbon nanofibers prepared by electrospinning, J. Raman Spectrosc., 35 (2004) 928-933.

[56] J. Tang, J. Yang, X. Zhou, Acetylene black derived hollow carbon nanostructure and its application in lithium-sulfur batteries, RSC Adv., 3 (2013) 16936-16939.

[57] S. Maldonado, K.J. Stevenson, Influence of nitrogen doping on oxygen reduction electrocatalysis at carbon nanofiber electrodes, J. Phys. Chem. B, 109 (2005) 4707-4716. 
[58] P.H. Matter, L. Zhang, U.S. Ozkan, The role of nanostructure in nitrogen-containing carbon catalysts for the oxygen reduction reaction, J. Catal., 239 (2006) 83-96.

[59] Y. Shao, J. Sui, G. Yin, Y. Gao, Nitrogen-doped carbon nanostructures and their composites as catalytic materials for proton exchange membrane fuel cell, Appl. Catal. B-Environ., 79 (2008) 89-99.

[60] W.Y. Wong, W.R.W. Daud, A.B. Mohamad, A.A.H. Kadhum, E.H. Majlan, K.S. Loh, Nitrogen-containing carbon nanotubes as cathodic catalysts for proton exchange membrane fuel cells, Diam. Relat. Mater., 22 (2012) 12-22.

[61] T. Ikeda, M. Boero, S.-F. Huang, K. Terakura, M. Oshima, J.-i. Ozaki, Carbon alloy catalysts: Active sites for oxygen reduction reaction, J. Phys. Chem. C, 112 (2008) 14706-14709. [62] H. Niwa, K. Horiba, Y. Harada, M. Oshima, T. Ikeda, K. Terakura, J.-i. Ozaki, S. Miyata, Xray absorption analysis of nitrogen contribution to oxygen reduction reaction in carbon alloy cathode catalysts for polymer electrolyte fuel cells, Journal of Power Sources, 187 (2009) 93-97. [63] R.A. Sidik, A.B. Anderson, N.P. Subramanian, S.P. Kumaraguru, B.N. Popov, $\mathrm{O}_{2}$ Reduction on graphite and nitrogen-doped graphite: Experiment and theory, J. Phys. Chem. B, 110 (2006) 1787-1793.

[64] E. Antolini, J. R. C. Saldago, M. J. Giz, and E. R. Gonzalez, Effects of geometric and electronic factors on ORR activity of carbon supported Pt-Co electrocatalysts in PEM fuel cells, Int. J. Hyd. Energy, 30 (2005) 1213-1220.

[65] V. R. Stamenkovic, B. S. Mun, K. J. J. Mayrhofer, P. N. Ross, and N. M. Markovic, Effect of surface composition on electronic structure, stability, and electrocatalytic properties of Pttransition metal alloys: Pt-skin versus Pt-skeleton surfaces, J. Am. Chem. Soc., 128 (2006) 8813-8819. 
[66] L. A. Kibler, A.M. El-Aziz, R. Hoyer, D.M. Kolb, Tuning reaction rates by lateral strain in a palladium monolayer. Angew. Chem. Int. Ed. 44 (2005) 2080-2084.

[67] A. Groß, Reactivity of bimetallic systems studied from first principles, Top. Catal., 37 (2006) 29-39.

[68] J. R. Kitchin, J. K. Nørskov, M. A. Barteau and J. G. Chen, Role of strain and ligand effects in the modification of the electronic and chemical properties of bimetallic surfaces, Phys. Rev. Lett., 93 (2004) 156801.

[69] A. Schlapka, M. Lischka, A. Groß, U. Kösberger, P. Jakob, P. Surface strain versus substrate interaction in heteroepitaxial metal layers: Pt on Ru(0001). Phys. Rev. Lett., 91 (2003) 016101.

[70] Y. Gauthier, M. Schmid, S. Padovani, E. Lundgren, V. Bus, G. Kresse, J. Redinger, P. Varga, Adsorption sites and ligand effect for co on an alloy surface: A direct view, Phys. Rev. Lett., 81 (2001) 036103.

[71] C. Wang, M. Chi, D. Li, D. Strmcnik, D. van der Vliet, G. Wang, V. Komanicky, K. C. Chang, A. P. Paulikas, D. Tripkovic, J. Pearson, K. L. More, N. M. Markovic, V. R. Stamenkovic, Design and synthesis of bimetallic electrocatalyst with multilayered Pt-skin surfaces, J. Am. Chem. Soc., 133 (2011) 14396-14403.

[72] X. Tuaev, J.P. Paraknowitsch, R. Illgen, A. Thomas, and P. Strasser, Nitrogen-doped coatings on carbon nanotubes and their stabilizing effect on Pt nanoparticles, Phys. Chem. Chem. Phys., 14 (2012) 6444-6447.

[73] J. Fusy, J. Meneaucourt, M. Alnot, C. Huguet, J.J. Ehrhardt, Growth and reactivity of evaporated platinum films on $\mathrm{Cu}(111)$ : a study by $\mathrm{AES}$, RHEED and adsorption of carbon monoxide and xenon. Appl. Surf. Sci., 93 (1996) 211-220.

[74] Z. Yang, S. Ball, D. Condit, M. Gummalla, Systematic study on the impact of Pt particle 
size and operating conditions on PEMFC cathode catalyst durability, J. Electrochem. Soc., 158 (2011) B1439-B1445.

[75] Y. Shao, G. Yin, and Y. Gao, Understanding and approaches for the durability issues of Ptbased catalysts for PEM fuel cell, J. Power Sources, 171 (2007) 558-566.

[76] S. Ohyagi, T. Sasaki, Durability of a PEMFC Pt-Co cathode catalyst layer during voltage cycling tests under supersaturated humidity conditions, Electrochim. Acta, 102 (2013) 336-341.

[77] L. Dubau, M. Lopez-Haro, L. Castanheira, J. Durst, M. Chatenet, P. Bayle-Guillemaud, L. Guétaz, N. Caqué, E. Rossinot, F. Maillard, Probing the structure, the composition and the ORR activity of $\mathrm{Pt}_{3} \mathrm{Co} / \mathrm{C}$ nanocrystallites during a $3422 \mathrm{~h}$ PEMFC ageing test, Appl. Catal. B-Environ., $142-143$ (2013) 801-808.

[78] S. Hidai, M. Kobayashi, H. Niwa, Y. Harada, M. Oshima, Y. Nakamori, T. Aoki, Changes in electronic states of platinum-cobalt alloy catalyst for polymer electrolyte fuel cells by potential cycling, J. Power Sources, 196 (2011) 8340-8345.

[79] L. Dubau, F. Maillard, M. Chatenet, L. Guetaz, J. André, E. Rossinot, Durability of Pt ${ }_{3} \mathrm{Co} / \mathrm{C}$ cathodes in a 16 cell PEMFC stack: Macro/microstructural changes and degradation mechanisms, J. Electrochem. Soc., 157 (2010) B1887-B1895.

[80] L. Dubau, J. Durst, F. Maillard, L. Guétaz, M. Chatenet, J. André, E. Rossinot, Further insights into the durability of $\mathrm{Pt}_{3} \mathrm{Co} / \mathrm{C}$ electrocatalysts: Formation of "hollow" $\mathrm{Pt}$ nanoparticles induced by the Kirkendall effect, Electrochim. Acta, 56 (2011) 10658-10667.

[81] S. Koh, M.F. Toney, P. Strasser, Activity-stability relationships of ordered and disordered alloy phases of $\mathrm{Pt}_{3} \mathrm{Co}$ electrocatalysts for the oxygen reduction (ORR), Electrochim. Acta, 52 (2007) 2765-2774. 
[82] M. Teliska, V.S. Murthi, S. Mukerjee, D.E. Ramaker, Correlation of water activation, surface properties, and oxygen reduction reactivity of supported Pt-M/C bimetallic electrocatalysts using XAS, J. Electrochem. Soc., 152 (2005) A2159-A2169.

[83] Y. Sugawara, T. Okayasu, A.P. Yadav, A. Nishitaka, T. Tsuru, Dissolution mechanism of platinum in sulfuric acid, J. Electrochem. Soc., 159 (2012) F779-F786.

[84] A. Parthasarathy, S. Srinivasan, A.J. Appleby, C.R. Martin, Temperature dependence of the electrode kinetics of oxygen reduction at the platinum/Nafion interface - A microelectrode investigation. J Electrochem Soc 139 (1992) 2530-2537. 


\section{Figure captions}

Figure 1. Schematic diagram for CCC support and Co-doped Pt/CCC catalyst synthesis.

Figure 2. (a) $\mathrm{N}_{2}$ adsorption/desorption isotherms and (b) $\mathrm{BJH}$ pore-size distribution curves obtained from the adsorption branch of CCC and Ketjen Black. The inset in (b) compares the pore size distribution in the range $0-10 \mathrm{~nm}$.

Figure 3. Comparison of (a) X-ray diffraction patterns and (b) Raman spectra of CCC and Ketjen Black.

Figure 4. HRTEM images of (a) CCC and (b) Ketjen Black.

Figure 5. (a) XPS survey scans of CCC and Ketjen Black and (b) deconvoluted N1s XPS spectra of CCC.

Figure 6. Comparison of X-ray diffractions of Pt/CCC and Co-doped Pt/CCC catalysts. Characteristic Pt and Co peaks in Pt/CCC catalyst are assigned in the inset.

Figure 7. HRTEM images of fresh (a) Pt/CCC, (b) Co-doped Pt/CCC, and (c) commercial Pt$\mathrm{Co} / \mathrm{C}$, and (d) commercial $\mathrm{Pt} / \mathrm{C}$ catalysts. Scale bar is $20 \mathrm{~nm}$.

Figure 8. Comparison of measured activities of (a) Co-doped Pt/CCC, (b) commercial Pt-Co/C, and (b) commercial Pt/C catalysts as a function of cycle number. The activities were measured under the following operating conditions: $\mathrm{H}_{2} / \mathrm{O}_{2}$ (2/9.5 stoic.), $80{ }^{\circ} \mathrm{C}, 100 \% \mathrm{RH}$, and $150 \mathrm{kPa}_{\mathrm{abs}}$. back pressure.

Figure 9. XEDS particle line-scan of Co-doped Pt/CCC catalyst (fresh).

Figure 10. Summary of measured activity degradation of Co-doped Pt/CCC, commercial Pt$\mathrm{Co} / \mathrm{C}$, and commercial $\mathrm{Pt} / \mathrm{C}$ catalysts as a function of cycle number.

Figure 11. XEDS particle line-scan of Co-doped Pt/CCC catalyst (after 30,000 cycles). 
Figure 12. Normalized ECSA plot of Co-doped Pt/CCC, commercial Pt-Co/C, and commercial $\mathrm{Pt} / \mathrm{C}$ catalysts as a function of cycle number. ECSAs were calculated from cyclic voltammograms obtained between 0.05 and $0.6 \mathrm{~V}$ (vs. RHE) at $80{ }^{\circ} \mathrm{C}$. Fully humidified $\mathrm{H}_{2}(75$ sccm) and $\mathrm{N}_{2}$ (200 sccm) were supplied to the anode and the cathode, respectively.

Figure 13. HRTEM images and particle size distribution for (a) Co-doped Pt/CCC and (b) commercial $\mathrm{Pt} / \mathrm{C}$ catalysts before and after 30,000 cycles. Scale bar is $20 \mathrm{~nm}$.

Figure 14. Comparison of X-ray diffraction patterns of Pt/C, Co-doped Pt/CCC (fresh powder), and Co-doped Pt/CCC (after 30,000 cycles).

Figure $15 . \mathrm{H}_{2}-\mathrm{O}_{2}$ fuel cell polarization curves of Co-doped $\mathrm{Pt} / \mathrm{CCC}$ catalyst (initial and after 10,000 and 30,000 cycles). The cell was operated at $80{ }^{\circ} \mathrm{C}, 100 \% \mathrm{RH}$ with a constant flow of $\mathrm{H}_{2} / \mathrm{O}_{2}$ (750/750 sccm). No back pressure was applied during the measurement.

Figure 16. Cyclic voltammograms of Pt/CCC and Co-doped Pt/CCC. The measurements were carried out at room temperature by sweeping the potential from $0.05-1.1 \mathrm{~V}$ vs. RHE at $50 \mathrm{mV} \mathrm{s}^{-1}$ in nitrogen-purged $0.1 \mathrm{M} \mathrm{HClO}_{4}$. 
Table 1. Pt:Co atomic compositions of Pt/CCC and Co-doped Pt/CCC given by ICP-AES, XPS, and XRF.

\begin{tabular}{|c|c|c|c|c|}
\hline \multirow{2}{*}{} & ICP & XPS & \multicolumn{2}{|c|}{ XRF } \\
\cline { 5 - 5 } & $1: 1$ & - & \multirow{2}{*}{ Initial } & \multirow{2}{*}{ After AST } \\
\hline Pt/CCC & $1.1: 1$ & $1.2: 1$ & $1.1: 1$ & $2.3: 1$ \\
\hline $\begin{array}{c}\text { Co-doped } \\
\text { Pt/CCC }\end{array}$ & & & & \\
\hline
\end{tabular}




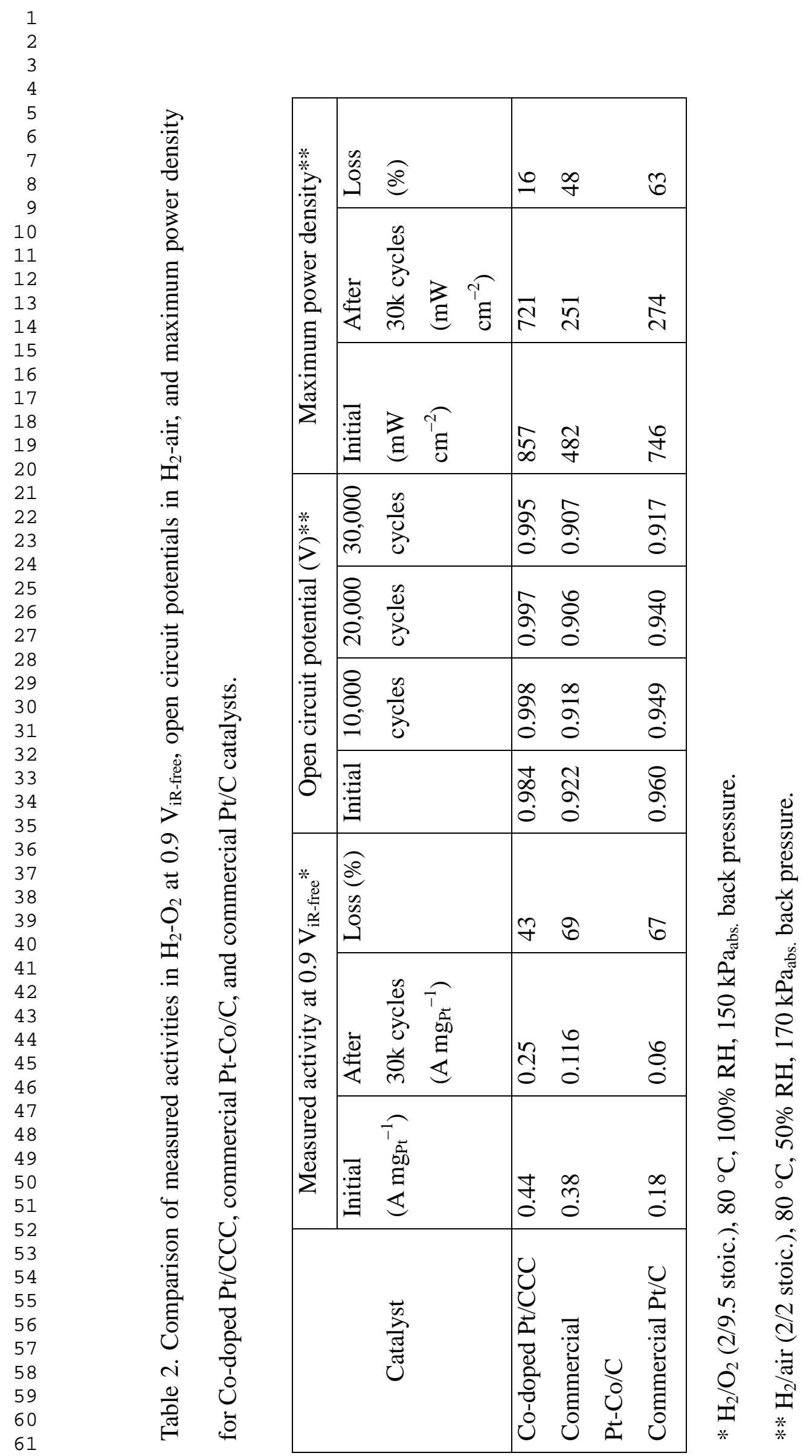




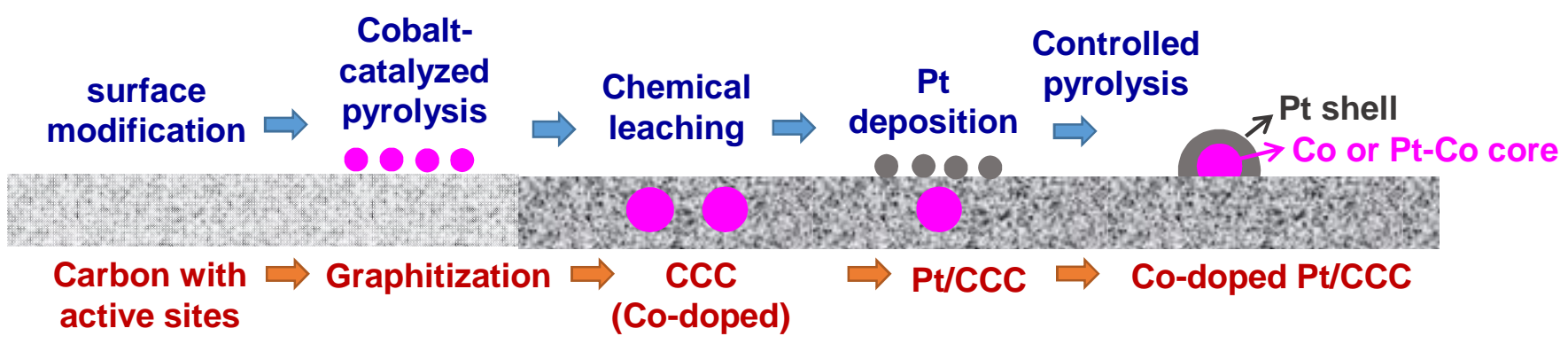

Figure 1 

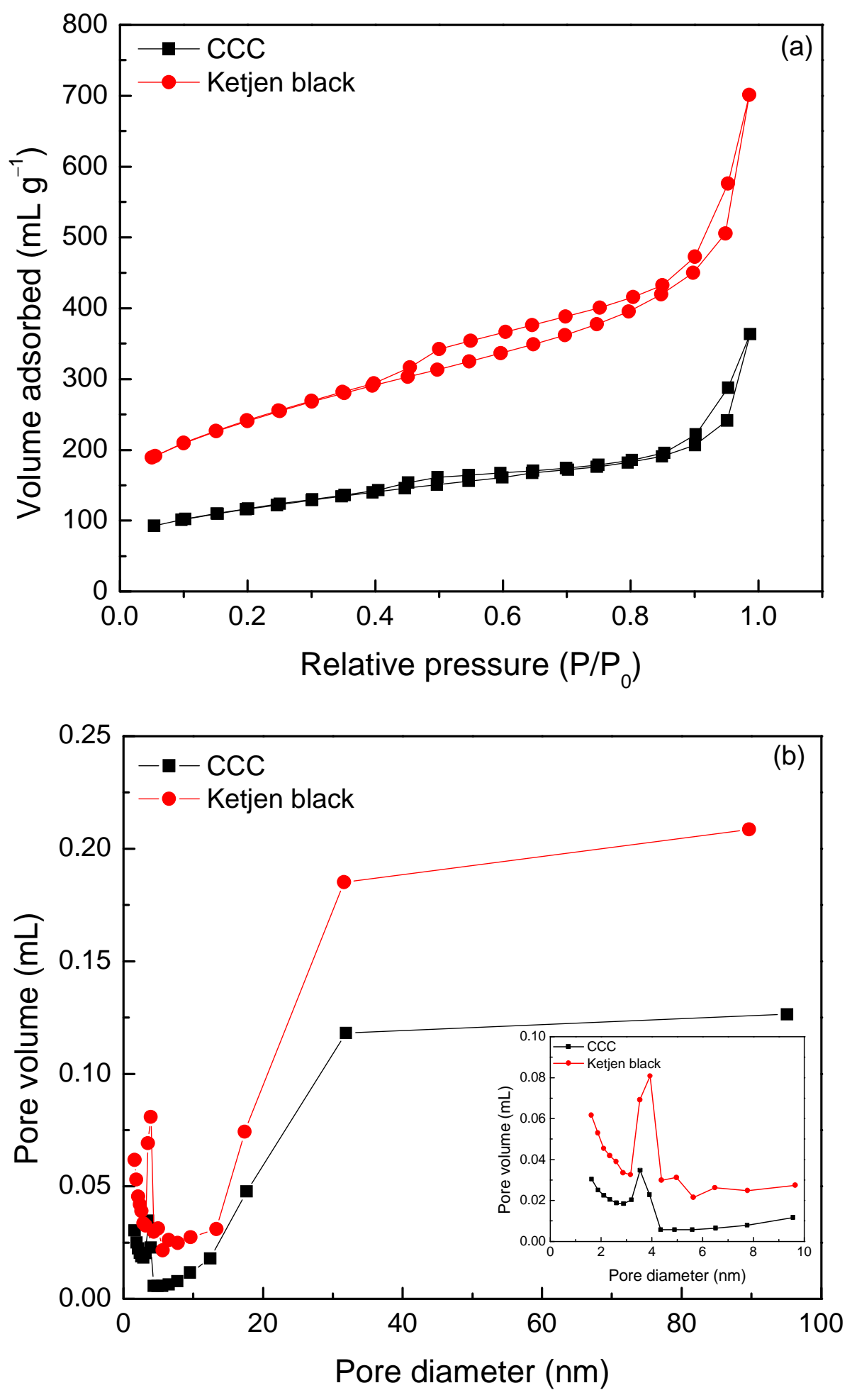

Figure 2 

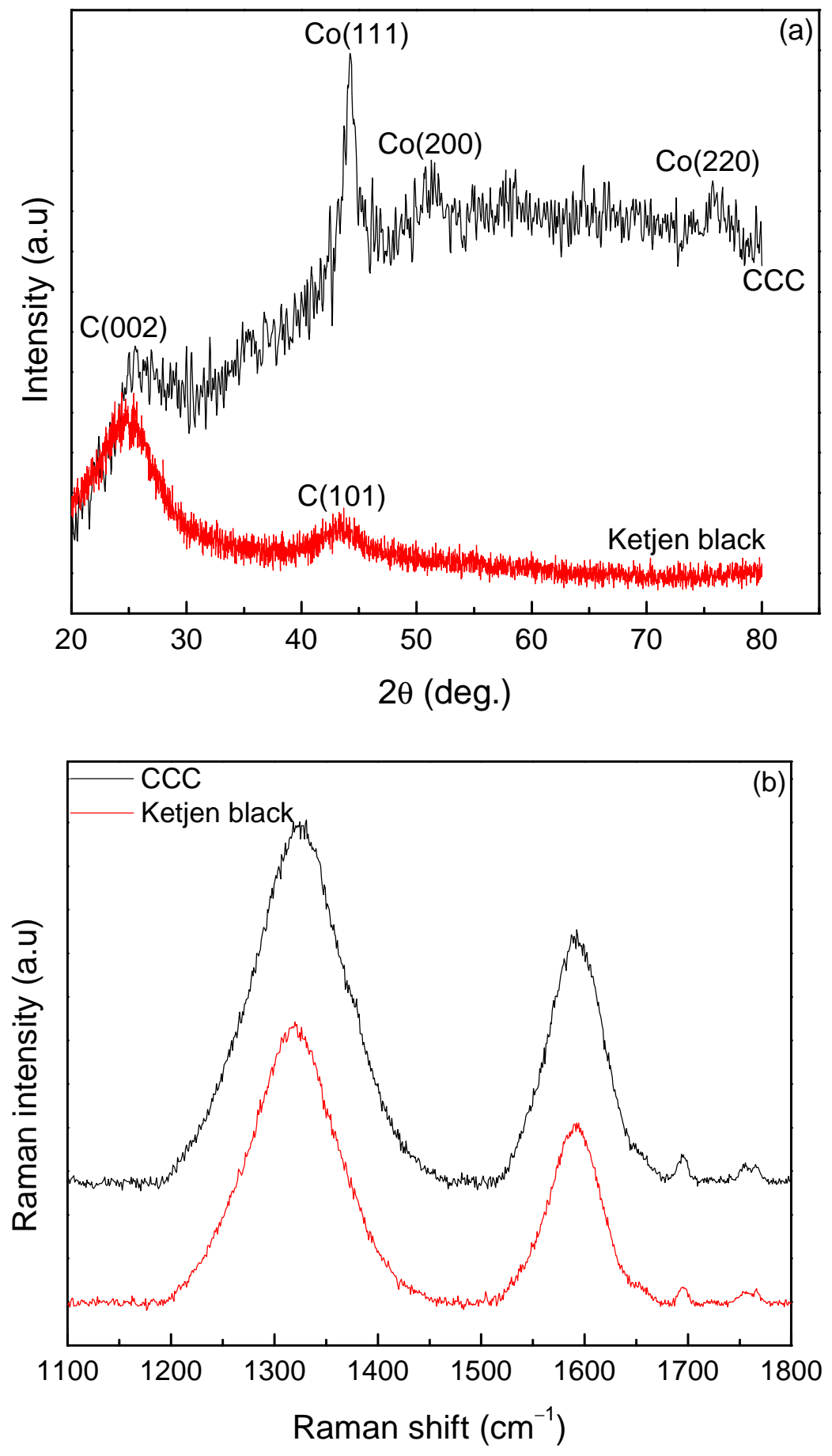

Figure 3 


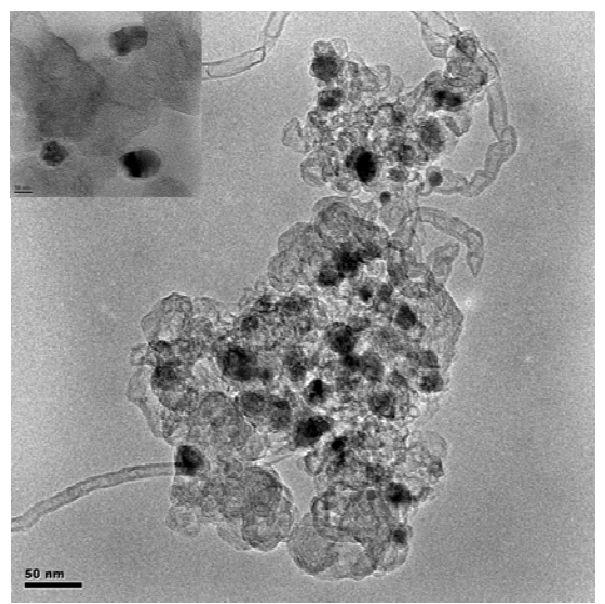

(a) $\mathrm{CCC}$

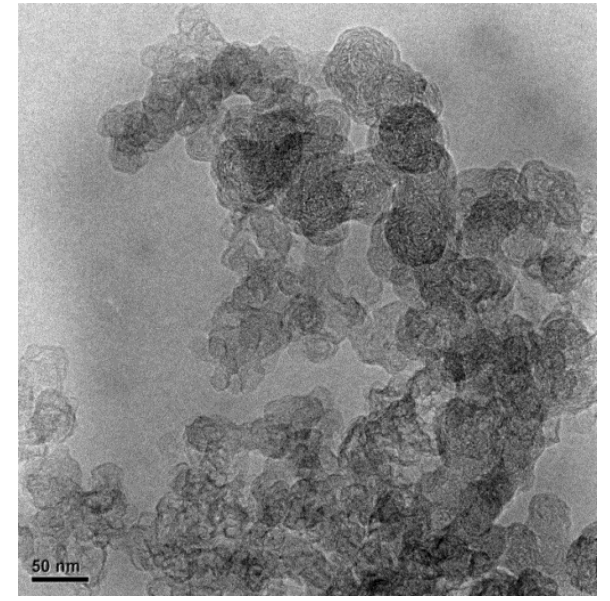

(b) Ketjen black

Figure 4 

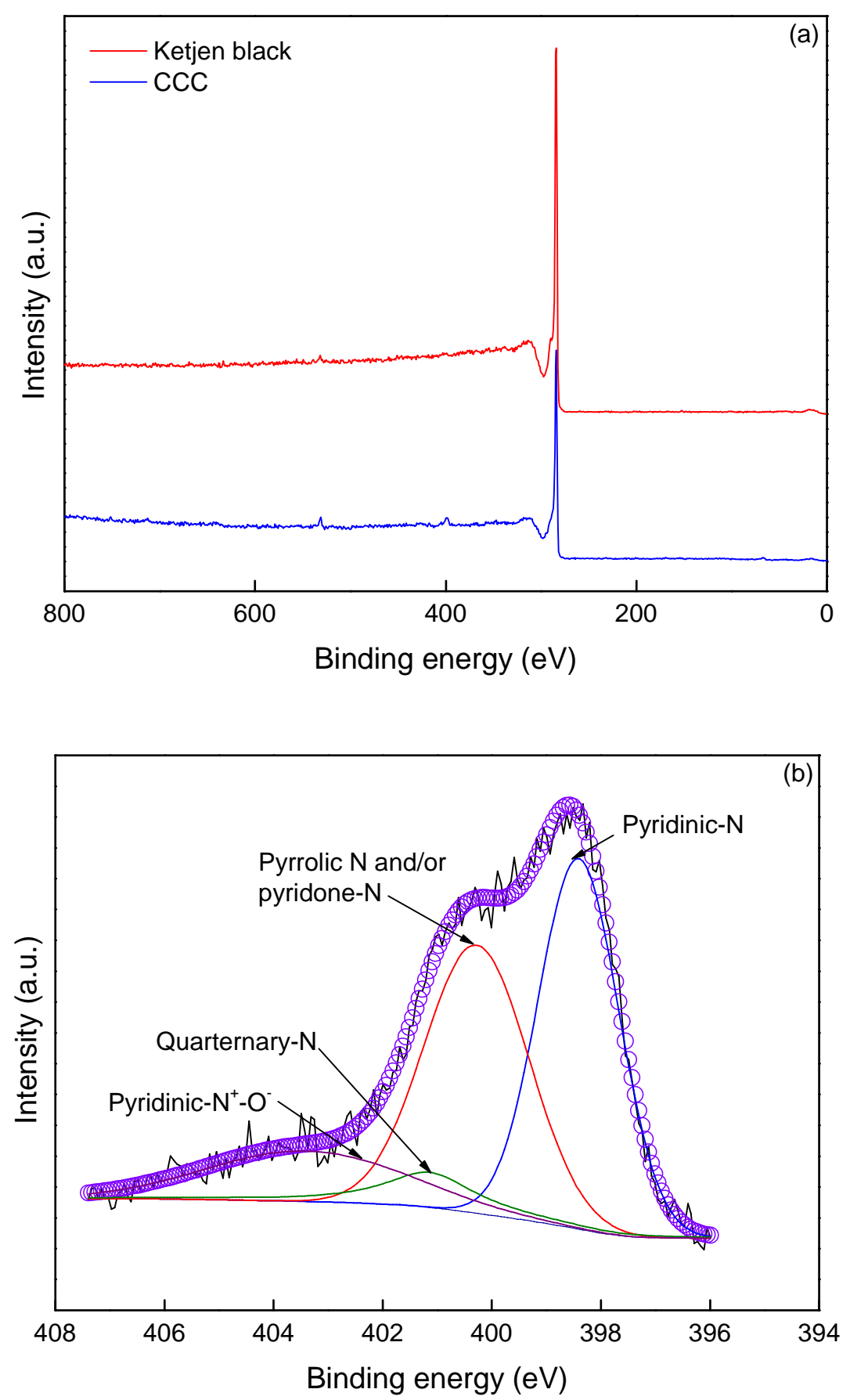

Figure 5 


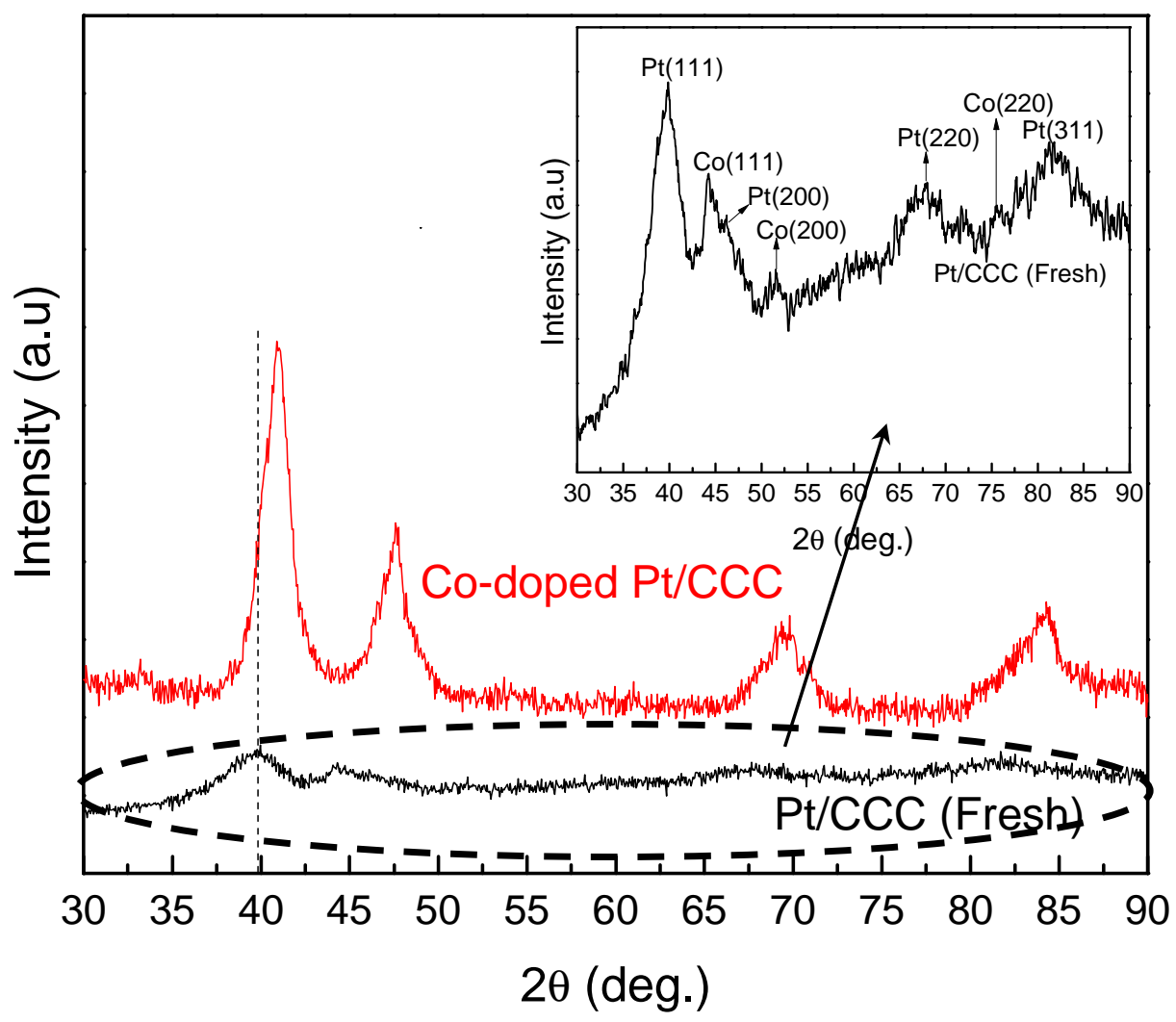

Figure 6 


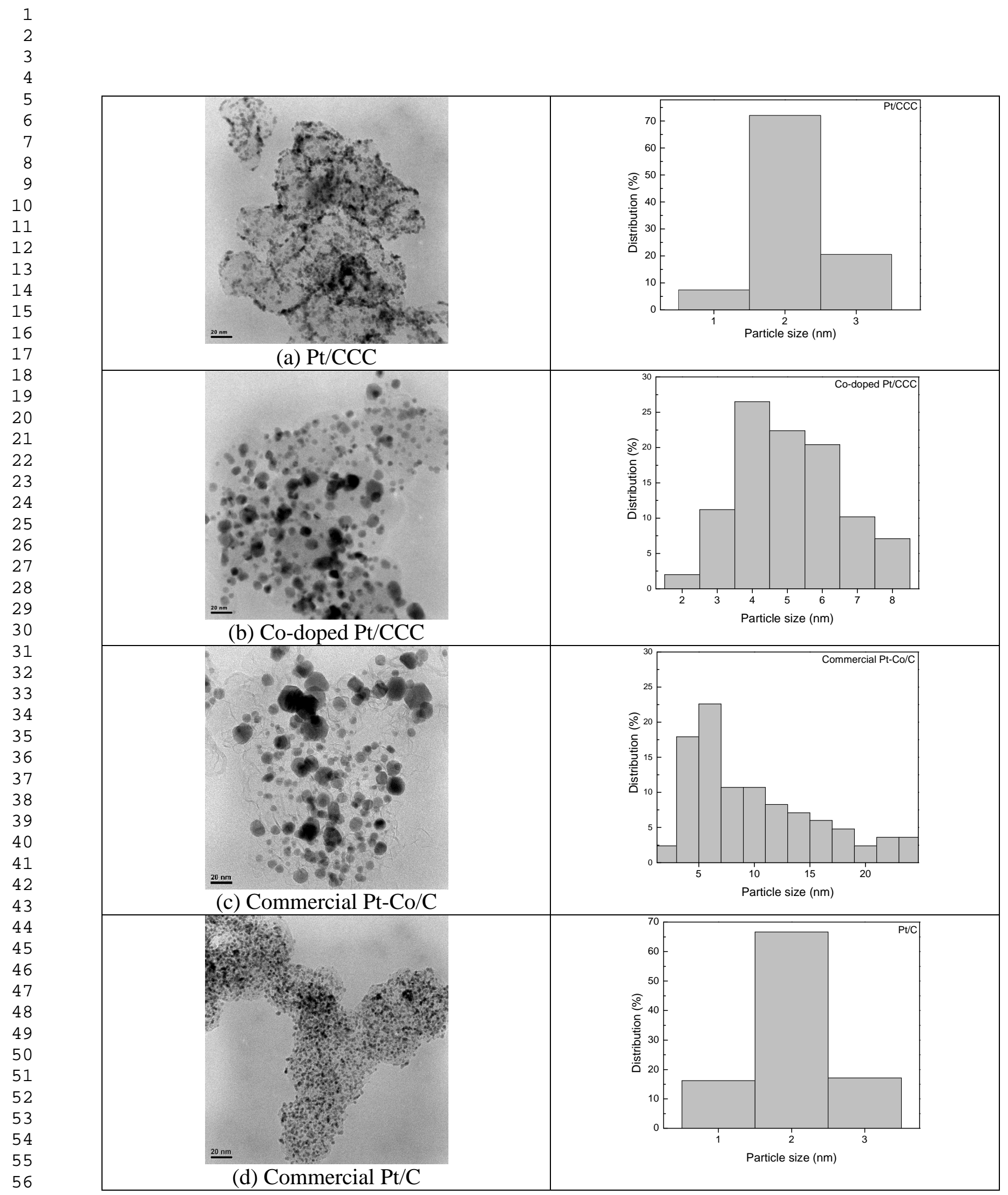



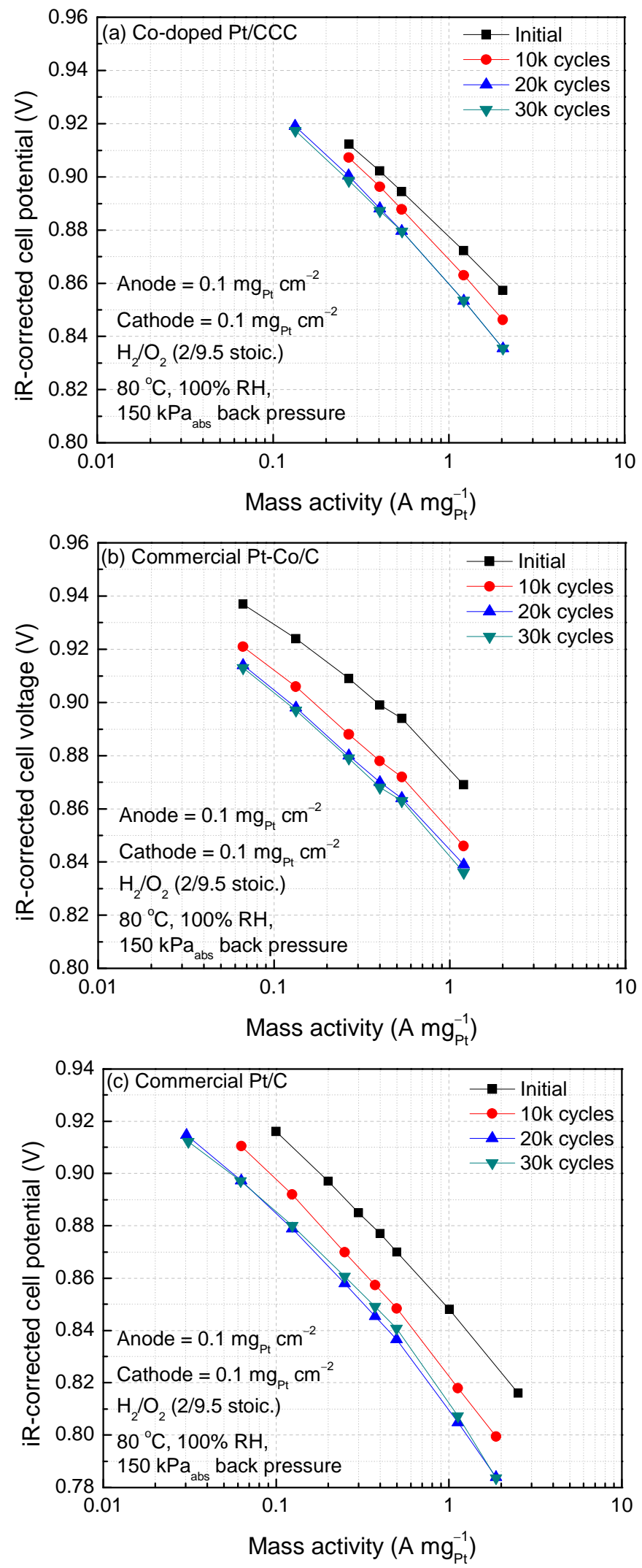

Figure 8 


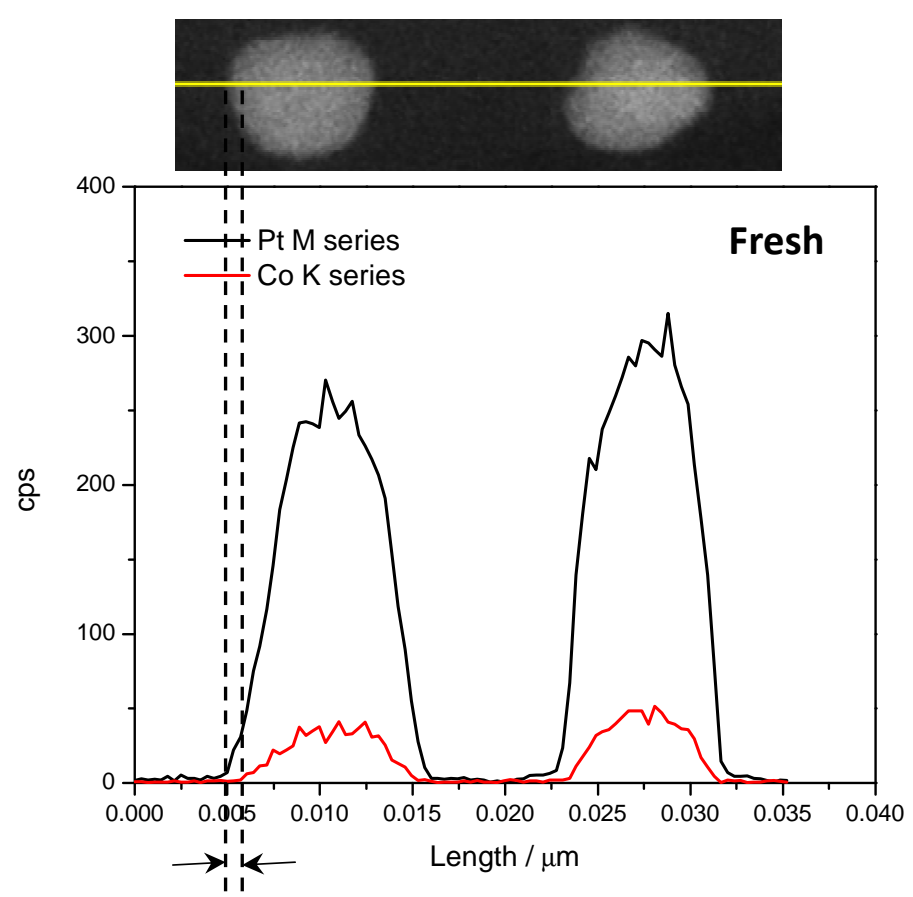

Pt shell thickness: $0.75 \mathrm{~nm}$

Figure 9 


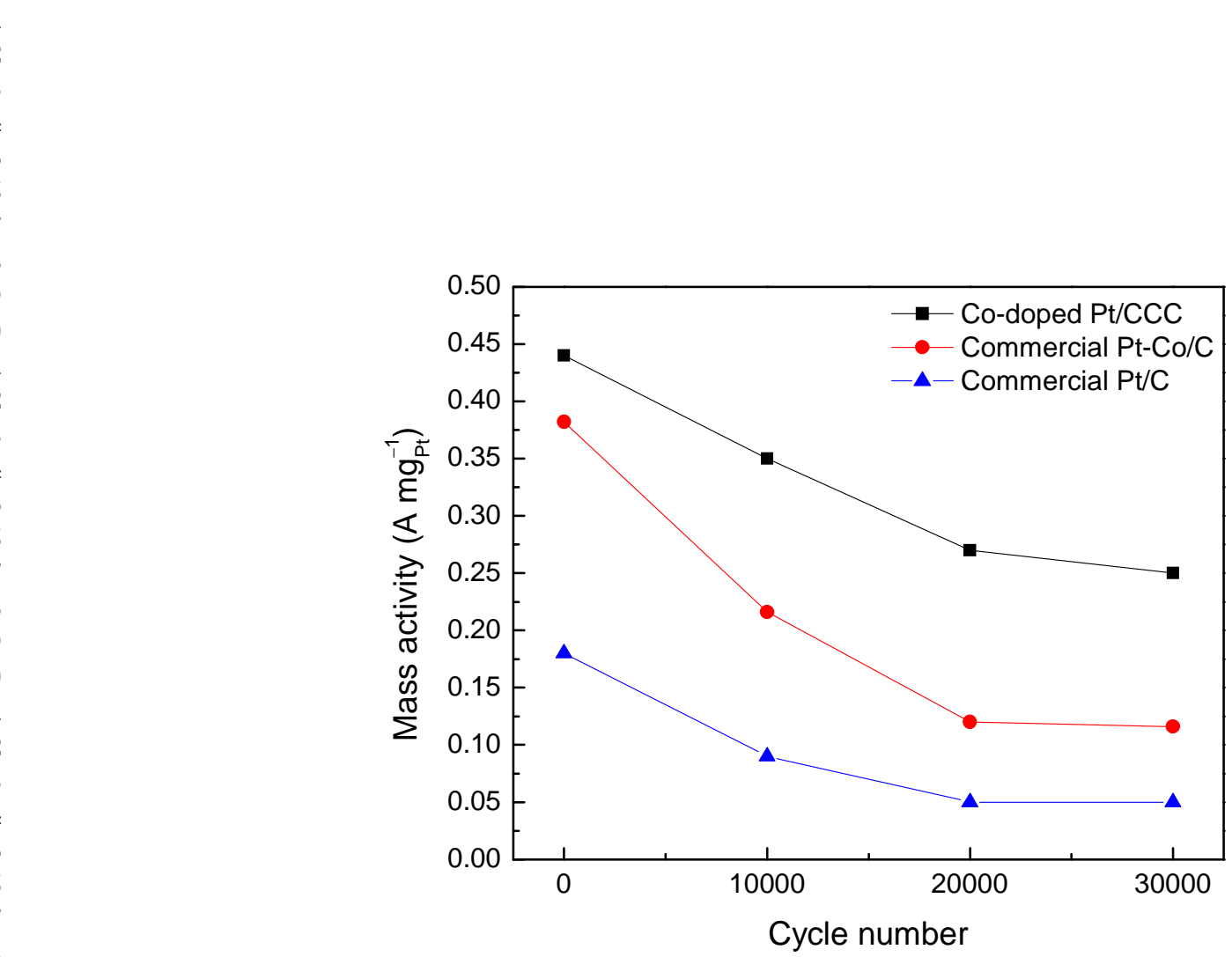

Figure 10 


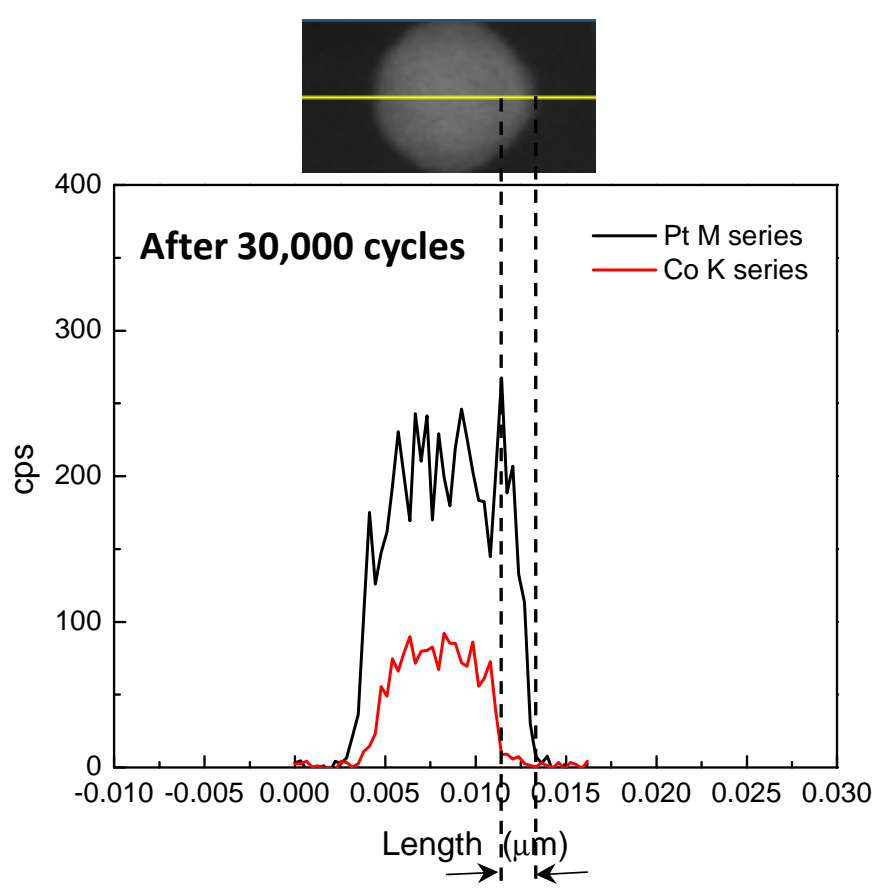

Pt shell thickness: $1.8 \mathrm{~nm}$

Figure 11 


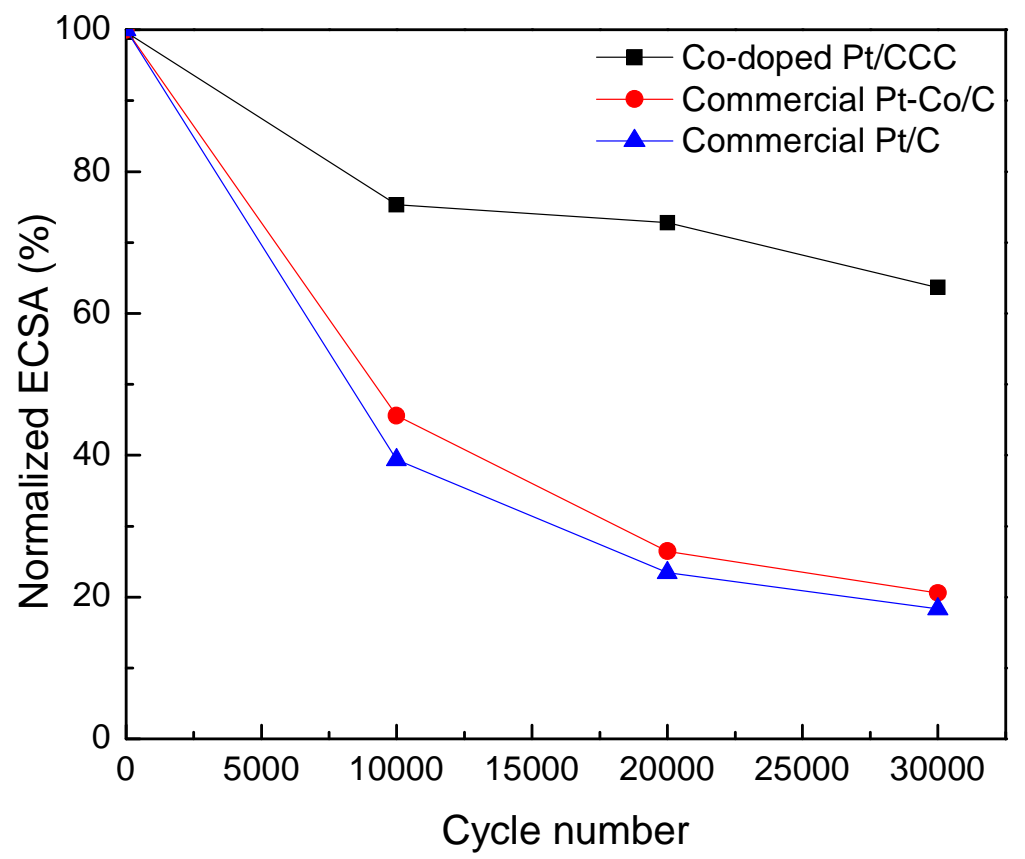

Figure 12 


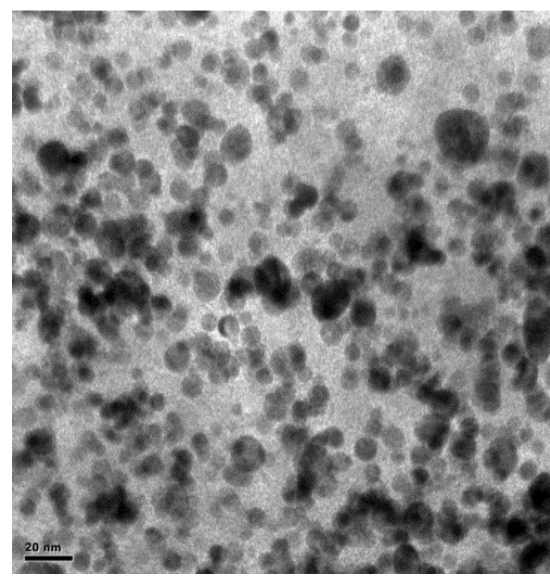

(a) Co-doped Pt/CCC (after 30,000 cycles)

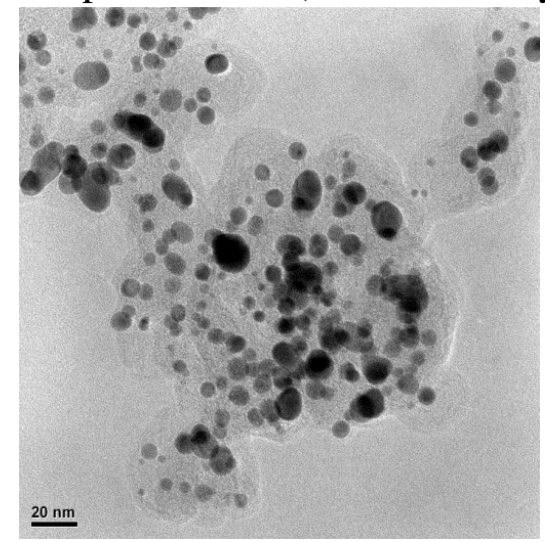

(b) Pt/C (after 30,000 cycles)
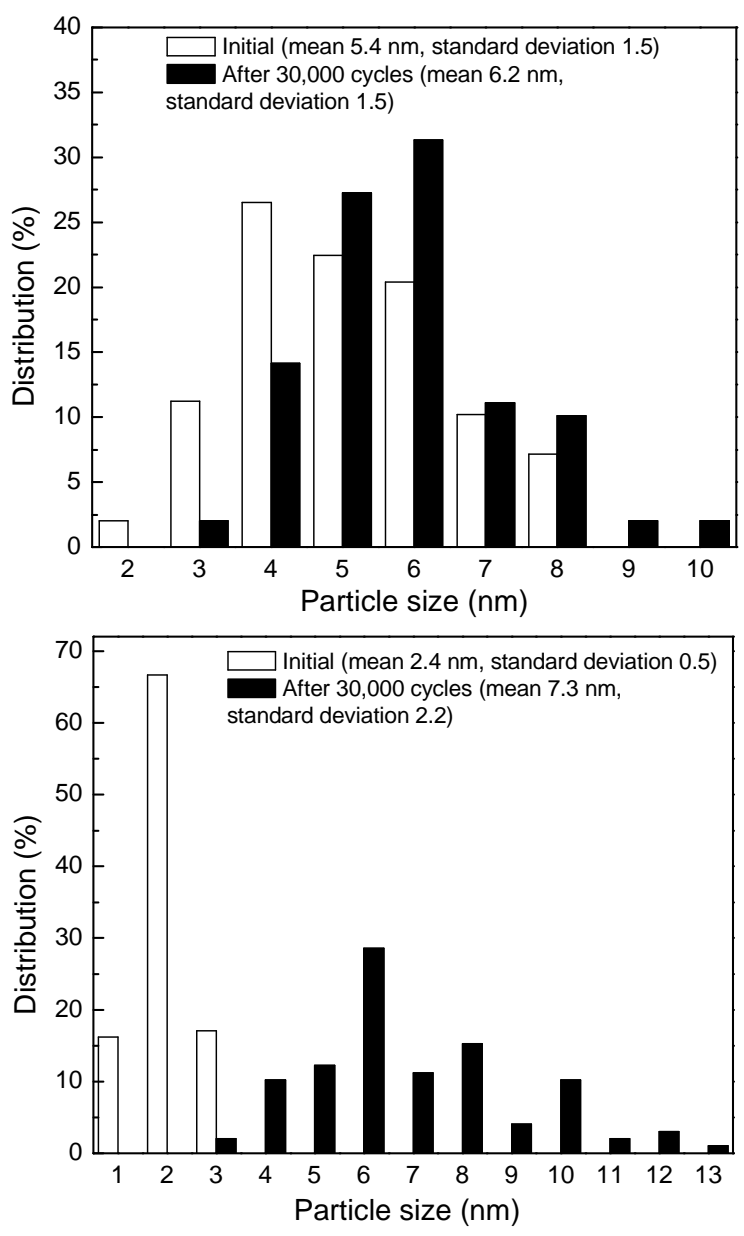

Figure 13 


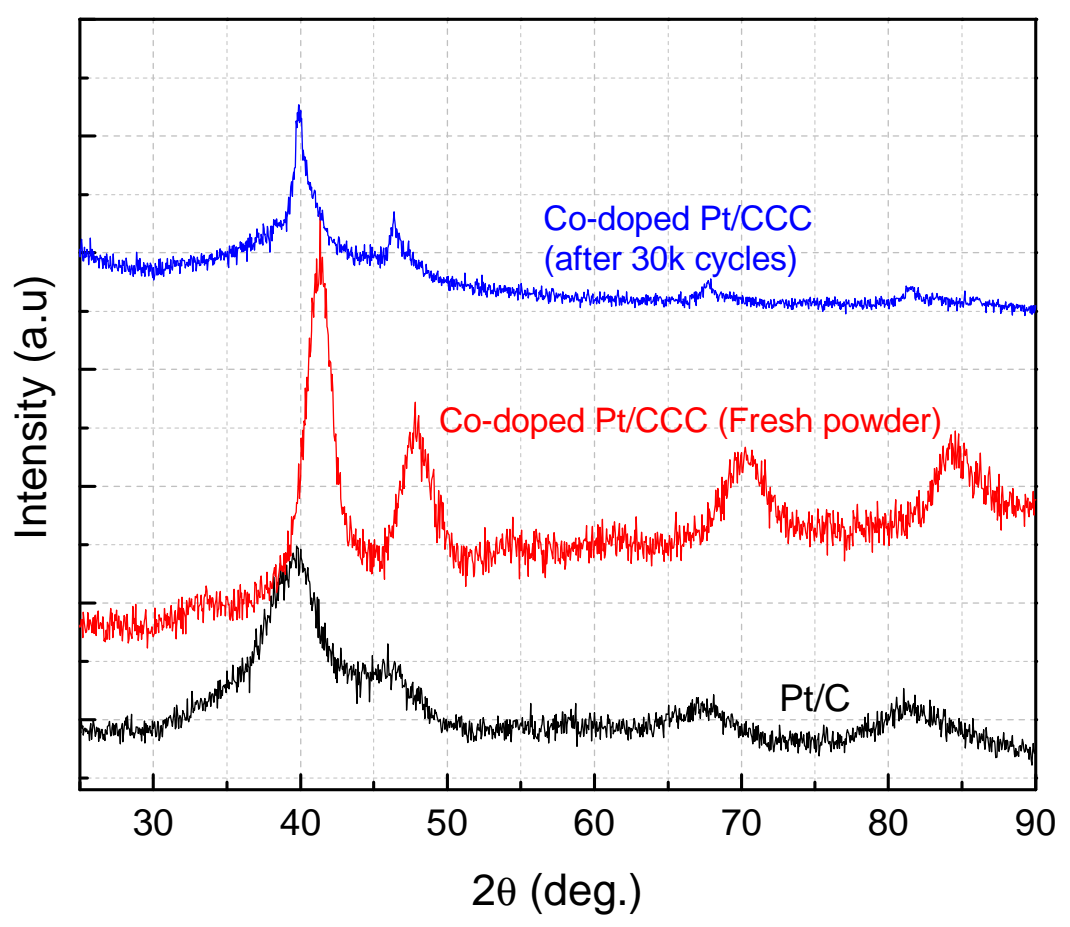

Figure 14 


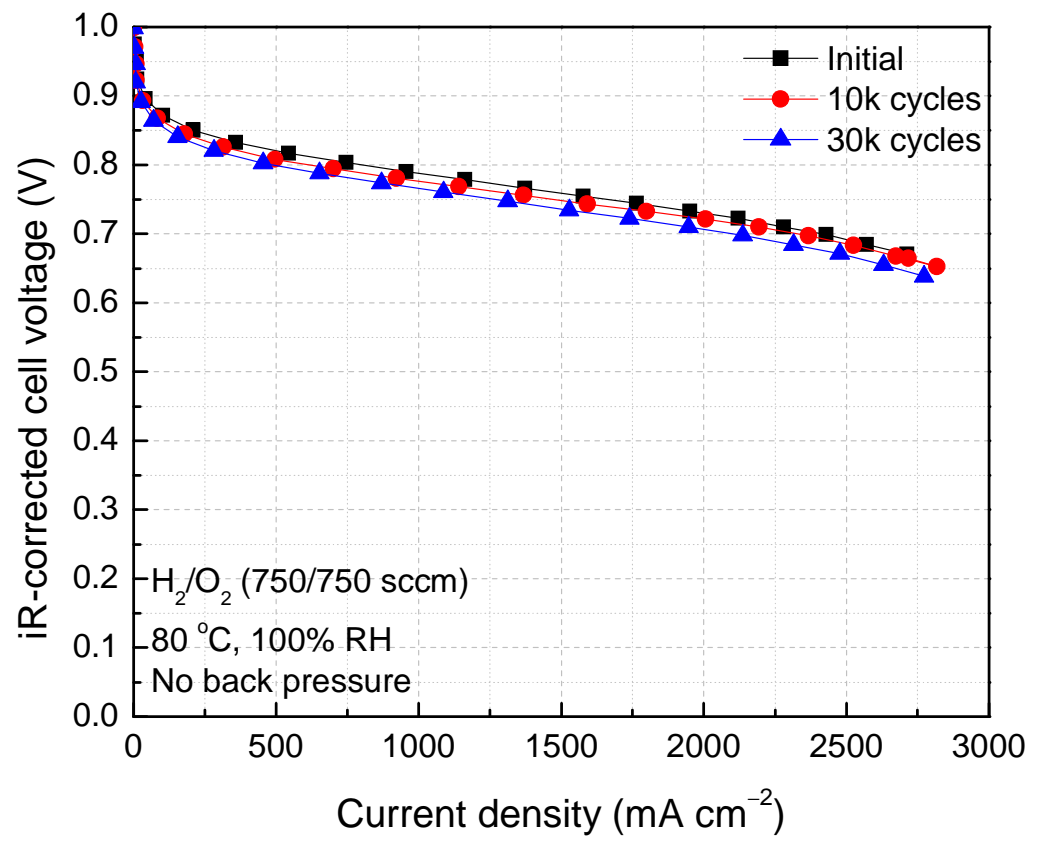

Figure 15 


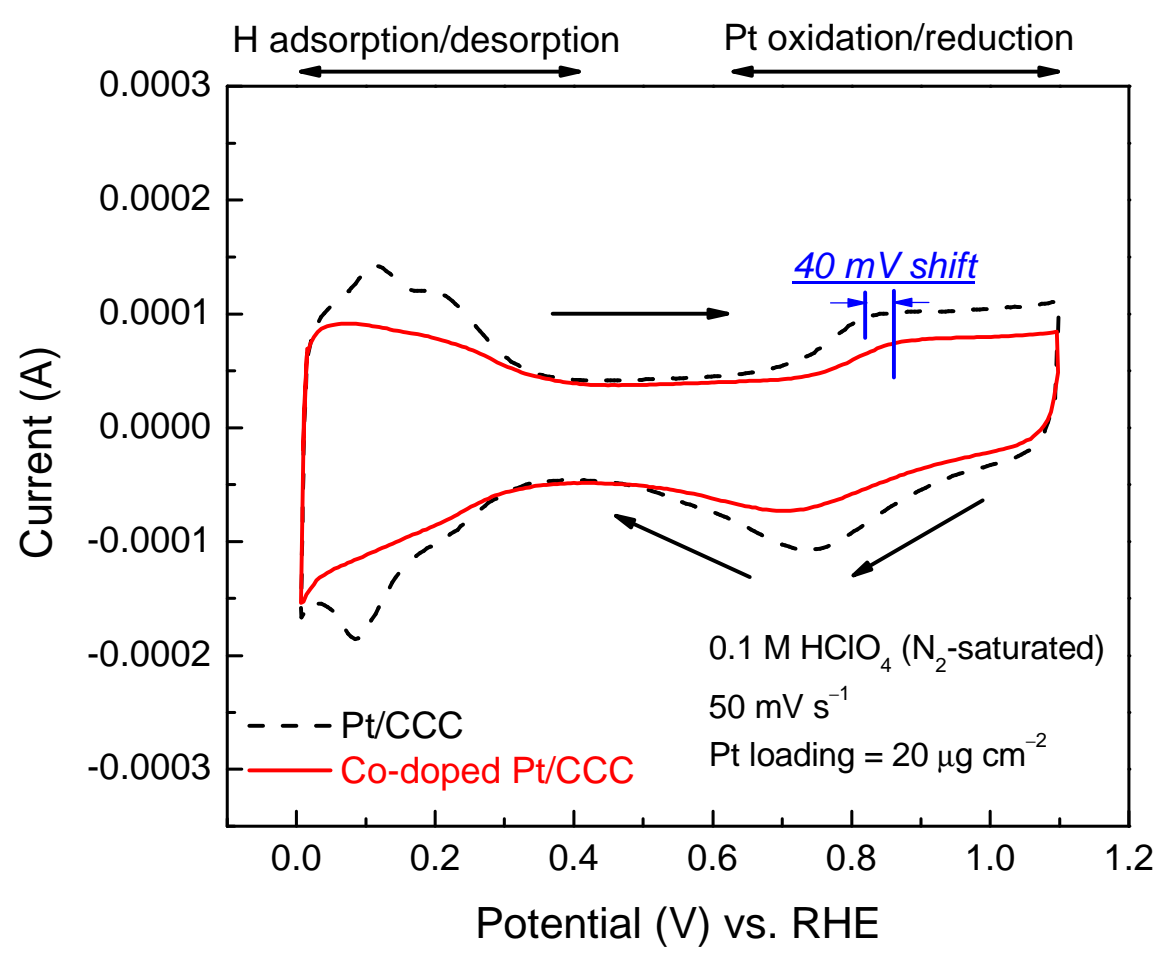

Figure 16 